\title{
Editorial
}

\section{An introduction to the Neogene stratigraphy of northern Belgium: present status}

\author{
Nö̈L VANDENBERGHE ${ }^{1}$ \& STEPHEN LOUWYE ${ }^{2}$ \\ ${ }^{1}$ Department Earth and Environmental Sciences, KU Leuven, Belgium; noel.vandenberghe@kuleuven.be. \\ ${ }^{2}$ Paleontology and Paleoenvironment, Department of Geology, Ghent University, Krijgslaan 281/S8, Ghent, Belgium; \\ stephen.louwye@ugent.be.
}

This Neogene-2020 volume presents elaborate reviews of our current understanding of Miocene and Pliocene deposits in Northern Belgium supported by new data. The review includes the latest research results notably from important field studies. This review volume should allow future progress in stratigraphic and palaeogeographic correlations of the Belgian Neogene with that of neighbouring countries. For this occasion, the Neogene databases of the Geological Survey of Belgium (GSB) and of the Flemish Community Databank Ondergrond Vlaanderen (DOV) are updated. Hence, reference to boreholes in these databases is made by their GSB and DOV code between brackets at the first mention of a borehole name in each paper.

The IUGS definition is followed for the Neogene as the System/Period containing Miocene and Pliocene Series/Epochs having its upper boundary with the overlying Quaternary System/Period between the Piazencian and Gelasian Stages/ Ages at 2.58 Ma (ICS chart, 2020).

\section{Historical developments in the understanding the Neogene of northern Belgium}

The present volume is intended as a step in the sequence of research efforts on Neogene deposits in northern Belgium that took off already at the end of the 19th century and resulted in a set of good quality geological maps. On these 1:40 000 geological maps made at the turn of the 19th and 20th centuries, the Miocene and the Pliocene deposits were identified and classified as 'Poederlien', 'Scaldisien', 'Diestien' and 'Boldérien' stages (Légende de la Carte géologique de la Belgique, 1909). In a revision of the legend (Légende générale de la Carte géologique détaillée de la Belgique, 1929) two new stages were added, the 'Amstélien' and the 'Anversien'.

More elaborate description and discussion of the Neogene deposits in Belgium (Tavernier, 1954) were published in the classical 'Prodrome d'une description géologique de la Belgique' (Fourmarier, 1954) introducing new data obtained during important public works for the extension of the Antwerp harbour (a.o. de Heinzelin de Braucourt, 1955a, b). The chronostratigraphy of the deposits was discussed and correlation schemes with the Netherlands and England, based on macrofossils, were attempted.

An important international Symposium on the Neogene of the Nordic countries including western France, was organised in the Ghent University in 1961 and the results were published as a memoir of the 'Société belge de Géologie' (de Heinzelin \& Tavernier, 1963). Palaeontological data in that volume also include micropalaeontological (foraminifera) and palynological studies. Correlations in the Nordic Basin and their integration in an international chronostratigraphic scheme were proposed. All lithological units in the Belgian Neogene known at that time were briefly described and mapped. In addition, several classical outcrops visited during a several-days field trip were described, and sections of the Antwerp harbour docks documented.
Sedimentological studies during the 1960s emphasised the use of grain-size and heavy mineral analysis as exemplified in several Neogene studies by Gullentops (1963) at the occasion of the ' $\mathrm{VI}^{\mathrm{e}}$ Congrès International de Sédimentologie HollandeBelgique'. Heavy mineral data for the Neogene deposits were summarised by Geets \& De Breuck (1991).

In the early 1970s new excavations in the Antwerp harbour were the occasion to start extensive studies of Neogene calcareous microfossils and molluscs of the Belgian Neogene at the University of Leuven. A reference result was the benthic foraminifera-based Neogene stratigraphy by De Meuter \& Laga (1976) and its correlation with the Netherlands (Doppert et al., 1979).

The need for a scientific base for the groundwater extraction in the Neogene deposits of North Belgium led to more drillings in the Campine, resulting in a set of several classical geological profiles across the Belgian Neogene prepared by the Geological Survey of Belgium and available in the archives of the survey (Laga, 1976). Besides drinking water, the Opgrimbie sand (Gullentops, 1973) and Mol silica-rich silver sand deposits represent another important economic value of the Neogene in North Belgium.

Detailed lithological and palaeontological characterisation of all the Neogene deposits of Belgium and their correlation with the Neogene deposits of the North Sea Basin countries was part of the International Geological Correlation Program (IGCP) 124 during the 1970 s and 1980 s, the results of which were published in an extensively documented volume edited by Vinken (1988).

A major breakthrough for the improvement of the stratigraphic position of the Neogene deposits, especially of the non-calcareous units, has been the discovery that many of the Neogene sand deposits contain stratigraphically useful dinoflagellate cysts allowing also the correlation with the international chronostratigraphy (Louwye, 2000, 2005; Louwye \& Laga, 2008). Consequently, since the beginning of the 21 st century dinoflagellate cyst biostratigraphy has become widely applied in modern studies of the Neogene of Belgium.

The organisation of the different Neogene lithological units into a sequence stratigraphic logic has been proposed by Vandenberghe et al. $(1998,2004)$ and for the Pliocene by Louwye et al. (2004). In the extensive description of the geology of Flanders edited by Borremans (2015) brief review summaries of the Miocene and Pliocene are described respectively by Louwye et al. (2015) and Laga et al. (2015).

The renewed 1:50 000 mapping of Flanders and Brussels in the late 1980s and the 1990s has used a purely lithostratigraphic approach making also a wide use of geophysical well logs (mainly natural gamma ray and resistivity logs) for the recognition of the units in the subsurface. Geophysical well logging for the reconnaissance of the Cenozoic was first introduced in Belgium in 1975 in the reference borehole at the 
Mol Nuclear Energy Research Centre (GSB 031W0237/DOV $\mathrm{B} / 1-0158$ ) and ever since gamma ray and resistivity logs have been a common stratigraphic tool in Neogene deposit studies.

The Neogene lithostratigraphy is continuously updated on the National Commission for Stratigraphy (NCS) website (https://ncs.naturalsciences.be/paleogene-neogene/neogene) and still largely reflects the stratigraphic scheme used on the new geological maps published between 1993 and 2010. Based on the studies in the 1970s, 1980s and 1990s, Laga et al. (2001) have (re-)defined the Neogene formations and listed the members in each formation. In the present Neogene volume, only the stratigraphic units already listed on the NCS website have their rank or lithology written with a capital letter.

Associated with the renewed 1:50 000 mapping, the archives of several federal and regional organisations as well as research institutes were digitised and collected in the DOV database (Jacobs et al., 1993; Vandenberghe et al., 2015). DOV, the regional Flanders Soil and Subsoil Database (https:// www.dov.vlaanderen.be) founded in 1996, is a network organisation with many subsurface-oriented stakeholders (De Keyzer et al., 2019). DOV manages Flanders subsurface data in the field of geology, geotechnics, groundwater and soil and serves as the information platform, available for re-use by external users (De Nil et al., 2020, this volume). Regarding geological data, the archive of the federal Geological Survey of Belgium (GSB) was the major data source. Since its creation in 1896 the GSB has collected data and stored a large collection of samples and cores. A digital version of borehole and outcrop data is available through http://collections.naturalsciences.be/ssh -geology-archives/arch. A virtual view in parts of these collections is possible on http://collections.naturalsciences.be/ ssh-geology/. The DOV database serves as a prime source for the 3D geological mapping program of Flanders, including the Neogene in North Belgium, by VITO, the Flemish Institute for Technological research (Matthijs et al., 2013; Deckers et al., 2019) and for the H3O-cross-border models with the Netherlands (Vernes et al., 2018; Deckers et al., 2014) by the GSB and VITO, or specific applications such as the Virtual Borehole (De Nil et al., 2018).

\section{Overview of main results}

Since the Chattian at the end of the Paleogene, a major tectonic reactivation of the Roer Valley Graben (RVG) took place in northern Belgium, causing a marked subsidence at its western border fault zone in NE Limburg. The RVG is part of the subsiding Lower Rhine Basin where river deposits together with thick brown coal seams were formed during the Neogene. Marine Chattian deposits, mainly sandy, glauconitic and often shell-bearing, occur in the subsidence-affected NE Limburg Graben Shoulder area whereas on the Antwerp Campine block to the west only a limited thickness of marine sandy Chattian deposits occur, documented to the Antwerp harbour area. These sandy deposits are described in the literature as the Voort Sand Formation. Both the base and the top of the Chattian deposits on the Campine shoulder are bound by unconformities as witnesses of the resumed tectonic activity. Geophysical log signatures of the Voort Sand, calibrated in the former Limburg coal mining reference area, show a NE thickening in the Limburg province between the Rijen-Mol-Beringen and the Reppel-Grote Brogel -Neeroeteren fault systems affecting in particular the upper part of the Voort Sand. The northeasternmost borehole of the Campine in the RVG, the Molenbeersel borehole, close to the Netherlands holds the thickest Chattian succession; it has a threefold subdivision that can be followed seismically in the Belgian part of the RVG and that is comparable to the Chattian succession in the Veldhoven borehole just across the Dutch border. Its lowest subdivision is correlated to the Voort Sand which includes a thin more clayey-sand zone also systematically identified in the Limburg Campine Graben Shoulder area. Following the Dutch nomenclature, the middle subdivision is the Wintelre Clay, formerly named Veldhoven Clay, and not to be confused with the thinner clayey zone within the Voort Sand. The upper sandy subdivision is unnamed in Belgium but in analogy to the Netherlands probably correlates to the Someren unit. In the Netherlands the name Veldhoven is now used as the name of the formation including the Voort, Wintelre and Someren Members and bound at its top by the Early Miocene Unconformity. The Wintelre and Someren Members are considered as lower Miocene in the Netherlands (Munsterman et al., 2020, fig. 8). However, in the Molenbeersel borehole no biostratigraphic information is yet available and on seismic lines in the Belgian area only a seismic facies change occurs at the top of the possibly Someren sand unit instead of a clear unconformity. The earlier proposed correlation of the clayey parts of the Veldhoven Formation in the Belgian Chattian with the classical Schneider \& Thiele subdivisions of the Lower Rhine area in Hager et al. (1998), remains uncertain if it only were because no depositional facies analysis of the clayey intervals in the Belgian Chattian is available.

Reinvestigation of the dinoflagellate cyst content in two reference boreholes in the Antwerp Campine has interpreted as Aquitanian the top of what was before considered as Chattian Voort Sand and suggested the incorporation of this thin Aquitanian top into the overlying Berchem Formation. The duration of the hiatus between the Chattian Voort Sand and the Miocene Berchem Formation is different in the two boreholes. The extensively investigated Berchem and Houthalen Formations had, until now, never delivered Aquitanian microfossils. Therefore, this surprising result calls for further detailed investigations of sediments and microfossils at the transition of the Oligocene to the Miocene in more locations. It also will require an adaptation of the stratigraphic interpretation of the reference geophysical logs of the Oligocene on the National Commission for Stratigraphy website.

Except for these thin Aquitanian layers and another not yet fully understood Aquitanian dinoflagellate analysis in the base of the Kiel Sand Member of the Berchem Formation, all sections of the Berchem and Bolderberg Formations revised in the present study interpret these formations as Burdigalian and Langhian with a few sections of early Serravallian age and therefore confirm the general presence of an important hiatus during the Aquitanian. The review has on the one hand confirmed the already earlier established lithostratigraphic subdivisions in the Berchem and Bolderberg Formations but has refined their dinoflagellate cyst stratigraphy hereby better positioning the different members of the two formations with respect to each other and understanding the palaeogeographic evolution in the area. At their top, outside the RVG, both formations are bound by a hiatus reflecting the tectonic rearrangement related to the Mid Miocene Unconformity (MMU) after which the Tortonian Diest Formation is filling the NE-SW oriented gully underlying the Hageland and the subsiding Campine Basin.

Of all Burdigalian units, the Edegem Member of the Berchem Formation is the oldest (except maybe for sediments of the same age at the base of the Houthalen Member of the Bolderberg Formation). The presence of a rare megamouth shark fossil in the Kiel Sand is newly documented and supports the existence of a global megamouth population during the Burdigalian. The new study of the Kiel Sand Member demonstrates that there is a systematic lithological difference with the overlying Antwerp Sand resulting in a distinct colour change. The latter sand is slightly finer-grained and contains more clay and glauconite. A characteristic strongly undulating 
shell layer forms the base of the overlying Antwerp Sand. The Kiel Sand is decalcified in the south of Antwerp city but picks up a rich mollusc fauna northwards in the city; in the same direction a mid to late Burdigalian hiatus develops in its top, producing the geometry of an unconformity with the overlying transgressive Antwerpen Sand. More to the North and East in the Antwerp Campine, the Berchem Formation is usually described as 'Antwerpen Sand' and members are no longer distinguished in the borehole descriptions done by the Geological Survey of Belgium. Although the limited information on Aquitanian deposits in the Campine, when combined with data from the Netherlands, suggests a transgression over the Campine area from the east at the very beginning of the Miocene. The more abundant dinoflagellate cyst data at the base of the main body of Burdigalian and Langhian deposits point to a transgression over the whole Campine coming in from the WNW and gradually transgressing eastwards.

The Zonderschot Member is a geographical variant of the Antwerp Member, lithologically difficult to differentiate from it and time equivalent with its early Langhian part. The data available for the quartz sand dominated Genk Member of the Bolderberg Formation also indicate a Langhian age to these much more nearshore to coastal deposits as compared to the underlying Burdigalian marine glauconitic Houthalen Member of the Bolderberg Formation. During the Langhian, the eastern Campine already came under more continental influence with the deposition of the Genk Member. Even in the underlying marine Houthalen Member heavy mineral content shows already a more continental influence than in the marine Berchem Formation in the northeast. A particular facies of silica sand including lignite developed in the Genk Member, namely the Opgrimbie sand. The seismically determined geometry of the mainly Langhian Genk Member resembles a NW prograding delta system relayed by the marine Antwerpen Sand Member. The geometry of the Opgrimbie sand facies and the gravel layers within this Genk Member needs further elucidation. The Opitter member, earlier mapped in east Limburg, is based on an erroneous stratigraphic interpretation and thereby also invalidates the Neogene activity of the Bree uplift as figured on the recent geological map.

In the Molenbeersel borehole (GSB 049W0226/DOV $\mathrm{kb} 18 \mathrm{~d} 49 \mathrm{w}-\mathrm{B} 226)$ in the RVG, the subsiding part of NE Limburg, the presence of an additional more than $150 \mathrm{~m}$ thick glauconitic sand unit is demonstrated by geophysical well logs, between the Genk Member and the base of the overlying Diest Formation; tentatively the name Molenbeersel member is proposed for this additional sand unit. In the RVG only two boreholes reach the Miocene strata, the Maaseik (GSB 049W0220/DOV kb18d49w-B220) and Molenbeersel boreholes. In the Maaseik borehole, a new biostratigraphic interpretation based on the dinoflagellate cysts and on the calcareous microfossil Bolboforma has confirmed the time equivalence of the originally identified 'Upper Antwerp' unit with the top of the Berchem and Bolderberg Formations in the Campine Block and in addition it has been shown that the originally identified 'unknown facies in the Campine' unit is mainly Serravallian explaining its absence over the Campine Block. The newly proposed Molenbeersel member identified in the Molenbeersel borehole, can probably be correlated to this Serravallian 'unknown facies in the Campine' unit, although relative dating is needed for confirmation. Therefore, the hiatus corresponding to the MMU event in the Campine Block is strongly reduced if present at all in this part of the RVG.

Regarding the Tortonian to Messinian Diest Formation, the sediments at the top of the Flemish Hills are no longer considered part of the Diest Formation and the same holds for the Gruitrode member, described during mapping in east Limburg. The glauconite-rich Diest Formation in the Antwerp area was reinvestigated in a temporary outcrop near the Antwerp International Airport (Deurne) and the classical local Deurne Member was redefined together with a newly proposed Borsbeek unit underlying it. Both are Tortonian but with respect to earlier dinoflagellate zonations, their chronostratigraphic position is improved by applying Bolboforma zonations now thought to be reliable since the study by King (2016). The Borsbeek unit is lithologically differentiated from the Deurne Member by its finer grain size and the presence of numerous marine mammal bones. The unit can be reduced to a coarse lag deposit. The shell-rich overlying Deurne Sand has an erosive trough-forming base even cutting down to the Berchem Formation and reminiscent of the classical erosive base of the Diest Formation in the Hageland thereby fuelling again the question of the relationship between the Campine (Kempen) Diest sand and the Dessel Sand Member. These two units in the Antwerp area are part of the southern Campine fringe of an early part of the Tortonian Diest Formation subunit that deposited the Hageland Diest sand in the south and includes also at least the lower part of the Dessel Member in the Campine. The Dessel Member is distinguished by its fine grain size with only its lower part containing carbonate. The Dessel Sand is attributed, in the literature, to the same Bolboforma zone as found in the Borsbeek and Deurne units. The microfossil-barren Hageland Diest sand unit represents the filling of an incised embayment at the southern limit of the North Sea that developed on the emerged land at the end of the Serravallian. However, a review of all proposed evolutionary schemes of events during this MMU related hiatus and the subsequent initial transgression demonstrates that our present understanding is not yet satisfactory. A favourite model is strongly relying on the lateral filling model in a confined embayment invoked for the first time to explain the incised filling of the Eocene Brussels Sand Formation in central Belgium (Houthuys, 2011). A new idea on the current system shaping the upper Miocene Hageland gully, has invoked the role of the geometry of the delta wedge of the mid Miocene Genk Sand. The younger depositional subunit of the Diest Formation, the Campine (Kempen) Diest sand unit, is filling the subsiding Campine Basin by westwards progradation during the late Tortonian to early Messinian starting from the palaeo-Meuse-Rhine river system mouth in the east. The heavy mineral content of the Dessel Member and the Campine (Kempen) Diest sand are different from the Hageland Diest sand and indicative of a different sediment provenance. The detrital clay minerals in the lower and middle Miocene Berchem Formation and the post MMU Diest Formation have a similar marine-origin composition. A clayey glauconitic sand occurs in the top of the Kempen Diest sand unit that is characterised by the unusual presence of Fe-vermiculite derived from altered glauconite-bearing soil in the provenance area.

In the Maaseik borehole in the RVG, the Serravallian 'upper Antwerp' unit is overlain by glauconite sand containing microfossils comparable to the Deurne and Dessel Members in the Antwerp and Campine area but also with Bolboforma calcareous microfossils pointing to an earlier Tortonian age than the Deurne and Dessel Sand Tortonian in the Campine area. Additionally, dinoflagellate data show that the overlying micarich quartz sand unit $X$ and the lowermost Waubach sand are still Tortonian. Besides, the latter is now recognised as the upper part of the Inden Formation. Indeed, geophysical well log analysis allows a neat subdivision of the former original Waubach unit in two parts and only the upper one continues to be considered as Waubach sand and gravel Member, whereas the lower part is now recognised as the Inden Formation in the Belgian part of the RVG. The Kieseloolite Formation hence 
starts only at the base of the upper Waubach sand and gravel Member. No precise age can be given for this base of the Kieseloolite Formation but from regional comparisons it is assumed to be situated at the beginning of the Messinian. Neither can the presence of a hiatus and an eventual Late Miocene Unconformity between the Inden and Kieseloolite Formations be confirmed; however, in the transition zone between both formations the sand is very coarse. The new stratigraphic data imply that the Inden Formation and an unnamed unit $\mathrm{X}$ in the Maaseik borehole are time equivalent with the Campine Diest sand unit.

East of the Kasterlee area, the basal part of the Messinian Kasterlee Formation is systematically clay-rich and named the clayey Kasterlee unit or clayey Kasterlee Formation. Underlying it occurs the Diest Formation that at its top also picks up clay laminae and therefore becomes hard to distinguish from the clayey basal part of the Kasterlee Formation. No prominent emersion features are observed in the top of the Campine (Kempen) Diest sand although a particular zone with detrital vermiculite exists in the top, now named as clayey Diest D4 unit. Still a practical boundary between the Diest and Kasterlee Formations has been documented in the Campine by integrating data from a newly described temporary outcrop at Heist-op-denBerg, geophysical borehole logs, geotechnical Cone Penetration Test (CPT) logs and sedimentological analyses on core samples. An issue needing further attention is the apparent coincidence of this Diest and Kasterlee Formations boundary with the transition from the dinoflagellate cysts biozones DN9 and DN10 while more to the west the main part of the prograding Campine (Kempen) Diest sand also contains DN10 dinoflagellates. Secondary vivianite nodules occur across the boundary between the Diest and Kasterlee Formations.

The analysis of the transition between the Diest Formation and the Kasterlee and Mol Formations in the central and eastern Campine area and its comparison to the type area of the Kasterlee Formation in the west has led to a new stratigraphic scheme. The classical sandy Kasterlee Formation west and southwest of Kasterlee village is bordered by a coastal clayey facies, named clayey Kasterlee unit or clayey Kasterlee Formation, occurring in the central and southern Campine including the Heist-op-den-Berg area. Between both sedimentary facies a limited zone with barrier sand is present. An interesting observation is that the transition of the clayey Kasterlee unit into the type sandy Kasterlee Sand area to the west can be traced on CPT logs. Above the clayey Kasterlee Formation and geometrically lateral of the type Kasterlee Sand, occurs a pale grey to white sand. It has been interpreted in the past as Kasterlee Sand devoid of glauconite, however lithologically and mineralogically this unit fits more the pale to white sands of the Mol Formation above it. It is therefore not excluded that a major erosion phase occurs between the underlying clayey Kasterlee unit and the overlying pale quartz sand. Although this possibility seems to be supported by the occurrence of clear erosion and reworking at that level in borehole cores in the central Campine, it is hard to evaluate the importance of this erosion and therefore an intra-formational erosive phase of minor palaeogeographical importance is also possible, and thus uncertainty remains. Because of this uncertainty this unit was labelled in the present Neogene volume at the same time as 'Kasterlee-sensu-Gulinck' unit pointing to the presumed chronostratigraphically equivalence with the type Kasterlee Formation meant by Gulinck and as 'lower Mol' unit stressing the lithostratigraphic equivalence with the Mol Formation. The precise nature of the relationship between these units needs further study.

In the central Campine boreholes the top of the clayey Kasterlee unit is recognised as a marked gamma ray (GR) signal increase. However, towards the eastern Campine area lithological control for the significance of this GR signal becomes missing. In the RVG area itself, such a signal corresponds to the top of the upper Tortonian quartz mica-rich sand unit $\mathrm{X}$ and not of the clayey Kasterlee unit. In the Lower Rhine area, the upper Tortonian Inden Formation and the Messinian upper Waubach sand and gravel Member are mainly fluviatile and therefore it is suggested that the end Tortonian to Messinian coastal lagoonal clayey Kasterlee unit in the central Campine, and even the 'lower Mol' or 'Kasterlee-sensuGulinck' unit, are bordering the fluviatile domain in the RVG domain. Besides, the heavy mineral association in this 'lower Mol' or 'Kasterlee-sensu-Gulinck' is comparable to the association in the upper Waubach sand and gravel Member at the base of the Kieseloolite Formation and hence at the base of the Messinian.

Direct chronostratigraphic control of the evolution within the fluviatile and swamp units of the Kieseloolite Formation in the Maaseik borehole situated in the RVG is poor, but as equivalent lithostratigraphic units are identified in the Dutch and German parts of the RVG, chronostratigraphic information is borrowed from these areas. The Brunssum clay and lignite complex including the intercalated Pey Sand developed during the Zanclean, which outside the RVG is mainly a period of emersion, except for the early Zanclean Kattendijk Formation and the mid to upper Zanclean incursions of the Broechem layer and the Luchtbal Crag in the Antwerp area in the west.

An analysis of CPT data has demonstrated the existence of a NE-SW oriented deep gully system at the basis of the Kattendijk Sand analogous to the gully system under the Hageland Diest sand. Consequently, two Kattendijk Sand units are distinguished, a lower one filling the incised gullies and the upper one transgressing over the wider area. After the Zanclean general emersion of the central and eastern Campine area, the balance between varying sea level and uplift-subsidence was restored in favour of a rising relative sea level and sedimentation resumed at the turn of the Zanclean to the Piacenzian with the development in the west of the Oorderen Member, at the base of a continuous series of units of the marine Lillo Formation, while in the east the fluviatile Mol Sand represents further expansion of the RVG river system over the Campine Shoulder area. In the $\mathrm{RVG}$, a complex of fine sand, clay and lignite formed, including the Reuver clay at the top of the Kieseloolite Formation. During the Piacenzian the fluviatile silica sand of the Mol Formation gradually or more probably stepwise encroached westwards, covering by the end of the Piacenzian the Lillo Formation in the Antwerp Campine where the fluviatile to coastal quartz sand became known under the name Merksplas Sand as it picks up more impurities in the quartz sand. The most eastward marine sand unit during the Piacenzian is the Poederlee Sand underlain by the Hukkelberg gravel. Its mineralogy testifies of its more landwards location compared to the Lillo Formation. Borehole logs in the area confirm the limited westwards extension of the Poederlee Sand. The Oorderen Member wedges out laterally of the lower part of the Poederlee Sand and consequently the top part of the latter is broadly time equivalent with the Kruisschans Member and the lower part of the Merksem Member. The Dutch Huijbergen borehole, located close to the Belgian Essen borehole, can be interpreted in terms of the stratigraphic subdivisions of the Belgian Lillo and Merksplas Formations based on wireline logs. Also, CPT records allow to consistently subdivide the Lillo Formation thereby clearly identifying a middle clay-enriched part although its correspondence to the existing lithostratigraphic units is not yet fully understood.

Regarding methodology, the interpretations summarised above have been obtained by the classical stratigraphic methods of investigation. Dinoflagellate cyst studies became a primary 
tool for biostratigraphy. Considerable progress has been possible since the common use of geophysical borehole logging, in particular natural gamma ray and resistivity records. The potential of using Cone Penetration Testing logs for stratigraphic use was demonstrated across several papers in this volume. The use of statistical handling and graphics of existing and newly acquired heavy mineral data, made this old sedimentary petrology method useful again and it allowed to recognise more subtle gradations in the evolution of marine versus continental provenance. Progress in the computer-aided systematic identification and accurate quantification of clay minerals also revives its potential in stratigraphy for characterising units, for understanding provenance and for demonstrating reworking and evaluating continental versus marine influences.

In the course of the redaction of the Neogene volume a data collection specially designed for the Neogene data has been constructed. This collection of reference data points of boreholes, outcrops and CPTs can be consulted either via https:// doi.org/10.20341/gb.2020.021-SM1 or in its DOV-environment via https://www.dov.vlaanderen.be/data/opdracht/2020-018771. It is meant to be the open reference dataset also for future research that can easily be accessed from the papers in the Neogene volume. It has required a thorough quality control of existing and newly delivered data and the scrutinizing of all data according to their degree of relevance for Neogene stratigraphy. This quality control is only possible through a close cooperation between the specialist geologists and the data managers. Developing specific data sets as developed for the Neogene in this volume should become a standard methodology for subsurface data in Flanders.

\section{Stratigraphic summary tables}

In this Neogene-2020 volume, existing lithostratigraphic subdivisions have been refined or questioned and new units are proposed. In several cases the chronostratigraphic frame and the palaeogeographical significance of these lithostratigraphic units have been improved. This has resulted in a set of four stratigraphic tables in which existing and newly proposed lithostratigraphic units are positioned with respect to their estimated chronostratigraphic age and to their geographical location. Obviously, such tables can only be as accurate as the data allow and their fate in the future is continuous adaptation following the ongoing research. Newly introduced units will need further discussion in the National Commission for Stratigraphy before becoming official and ranked in the stratigraphical hierarchy. Only units already officialised by NCS have their rank written with capital letter in the tables.

The advantage of positioning the lithostratigraphic units as accurate as possible with respect to their estimated chronostratigraphic age allows to visualise in the tables also the presence and duration of hiatuses during which unavoidably weathering and erosion occurred on the emerged land and which are essential components of the palaeogeographic evolution of the area. In compensation for the apparent lack of the physical importance of the units, the thickness of each stratigraphic subdivision is included with each unit in the table. The combination of time and thickness on the other hand allows to estimate sedimentation rates or sediment preservation rates.

Obviously, uncertainties are inherent and are indicated in the tables with question marks or dashed lines. Biozones are used to position the lithostratigraphic units in the chronostratigraphy. In the tables a lithostratigraphic unit holding a particular biozone is generally represented over the full biochron time interval which obviously might not be the case as biozones generally represent considerable time intervals.

As the tables are in $2 \mathrm{D}$ and presented along idealised West-
East profiles across North Belgium, more northern and southern areas are necessarily projected on the profile. The main geographical areas are Antwerp city and harbour, Antwerp Campine, Limburg Campine, Roer Valley Graben and in some cases specific areas are added such as Hageland and Brussels, Tienen, or Brabant area. Locations of some well-studied reference boreholes are also indicated along the profiles as are important fault systems.

In the legends of the tables below, we describe their main features and refer to the relevant literature for justification. When referring to a particular borehole for the first time, its archive code in the Geological Survey of Belgium (GSB) archives and its code in the DOV data collection, together with a hyperlink, are added between brackets after the borehole name. This is the way all data points are labelled in the different papers of this Neogene volume. They constitute the Neogene reference data points collected in the table in De Nil et al. (2020, this volume) in which the location names are arranged alphabetically.

\section{The Oligocene to Miocene Stratigraphic Table (Fig. 1)}

The time scale with magnetostratigraphy and NP zonations is after Coccioni et al. (2018) and was figured in Vandenberghe (2017, fig. 4); dinoflagellate zonations are after Munsterman et al. (2020) and Van Simaeys et al. (2004) with the Chattian base at the boundary between NSO5a and b. Calcareous nannoplankton zonation is after Steurbaut (1986). The span of the hiatus between base Chattian and top Rupelian deposits in Belgium is after Vandenberghe (2017) (see also Coccioni et al., 2018, fig. 10). Note that almost the entire hiatus is Rupelian and almost no Chattian is missing. The Asterigerina Horizon at the base of the Voort Sand and its correlation to the North Sea alternative NP24*/NP25* and the international biozonation is discussed in De Man et al. (2010). According to data in Van Simaeys et al. (2004) and Munsterman \& Deckers (2020, this volume) NSO5b and NSO6 are commonly present in the Belgian Chattian although some discrepancies can be noted when comparing biostratigraphic data in detail with the reference Rupelian-Chattian stratigraphy (Coccioni et al., 2018). The exact chronostratigraphic position of the top of the Voort Sand within NSO8 biozone is uncertain.

For the Antwerp harbour and the Campine area two sections with slightly different orientation are presented together with the stratigraphic position of the base of the overlying Berchem and Bolderberg Formations. Biozones and thickness data are based on the Ekeren borehole (GSB 015W0142/DOV GEO-60/2718A) (Vandenberghe et al., 2004) for the Antwerp harbour and on the Essen ONDRAF-NIRAS borehole (GSB 001E0071/DOV B/1-1092) (Van Simaeys, written com.), the Turnhout-Meerle 1:50 000 map sheet 8-2 (Buffel et al., 2002), and the Weelde (GSB 008E0133/DOV kb8d8e-B26) and ON-Mol-1 (GSB 031W0314/DOV ON-Mol-1) boreholes (Munsterman \& Deckers, 2020, this volume) for the Antwerp Campine. The Limburg Campine thickness data are after Dusar \& Vandenberghe (2020, this volume) and the biozone data from De Man et al. (2010, fig. 4). The clayey horizon with Schneider \& Thiele S\&T 06 code (Schneider \& Thiele, 1965), is discussed in Dusar \& Vandenberghe (2020, this volume) and its stratigraphic position is based on the ON-Mol-1 borehole.

The RVG thickness data are based on the Molenbeersel borehole (Deckers, 2015). As no biostratigraphic data are available in this borehole equivalent chronostratigraphic data are taken from Munsterman et al. (2020). The identification of the Schneider \& Thiele S\&T 06 horizon is based on Hager et al. (1998); these authors also interpreted the Wintelre Clay as equivalent to the Schneider \& Thiele S\&T 1 horizon. Note however that the S\&T 1 is positioned in the Chattian by Schäfer 

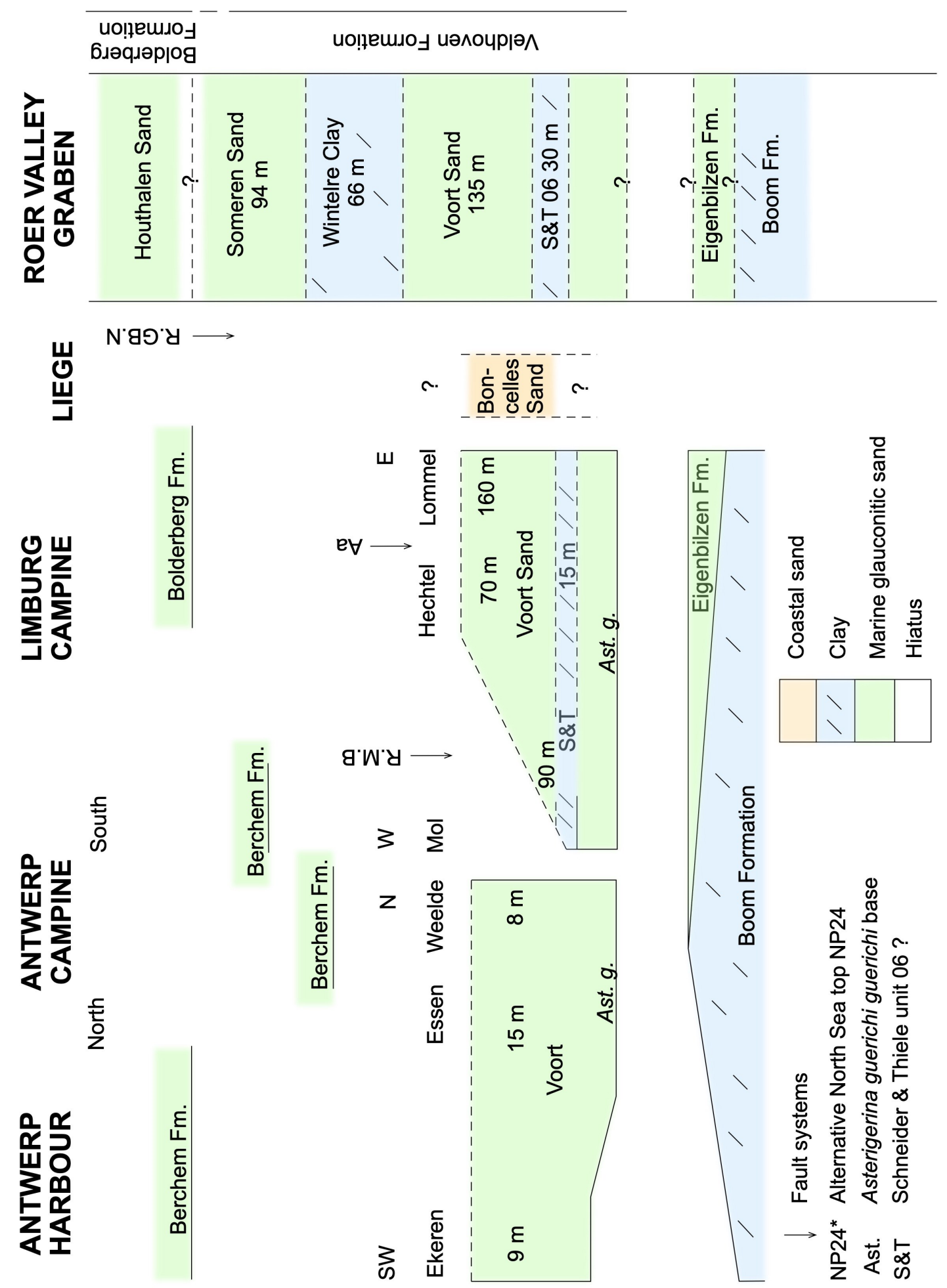
\& Utescher (2014, fig. 3) while the Wintelre Clay is positioned in the Aquitanian by Munsterman et al. (2020).

The chronostratigraphic position of the Boncelles Sand is poorly constrained (see Dusar \& Vandenberghe, 2020, this volume). The Rijen-Mol-Beringen (R.M.B), the Aa, and the Reppel-Grote Brogel-Neeroeteren (R.GB.N) fault systems are influencing the thickness development and therefore their approximate positions are indicated by vertical arrows.

\section{The lower and middle Miocene Stratigraphic Table (Fig. 2)}

The biozones are dinoflagellate cyst zonations: $\mathrm{M}$ (= Munsterman \& Brinkhuis, 2004), DN (= de Verteuil \& Norris, 1996) and D \& P (= Dybkjær \& Piasecki, 2010). Discrepancies exist between the zonation schemes and the correspondence between DN and D \& P zone boundaries, with red lines for firm correlation levels, is given in tables in Everaert et al. (2020, this volume) and in Munsterman et al. (2020). Louwye et al. (2020a, this volume) present a correspondence table between the three zonation schemes after Dybkjær \& Piasecki (2020). The North Sea Oligocene zones NSO are following Van Simaeys et al. (2005).

\section{Antwerp city and harbour, and Antwerp Campine}

The Burdigalian biochron age $C$. cantharellus for the main Berchem Formation mass is based on Louwye et al. (2020a, this volume). The ON-Mol-1 borehole situation with a very thin M2 Aquitanian interval at the base of the Berchem Formation above Chattian NSO6 and the very thin dinoflagellate Aquitanian M1 and M2 interval at the base of the Berchem Formation above Chattian NSO8 in the Weelde borehole situation, are reported in Munsterman \& Deckers (2020, this volume) and drafted as a lag deposits.

In the Antwerp city type area a marked laterally progressive hiatus at the level of DN3 or C. aubryae is present (Louwye et al., 2000; Everaert et al., 2020, this volume). It is unknown how this hiatus develops further to the north (Antwerp Campine) since in several boreholes in that area the characteristic $C$. aubryae and E. insigne zones are commonly present in the Berchem Formation (Louwye et al., 2020a, this volume). To the north and east in the Antwerp Campine the formation is not commonly subdivided in individual members and only reported as Antwerp Sand. The possible extension of the Edegem Sand suggested in the North Antwerp Campine is following Laga (1976) reporting it in the borehole Essen-Kalmthout (GSB 006E0110bis on profile PGL 77 /103/DOV kb7d6e-B239) based on clayey dark green sand samples in the borehole description by Gulinck (1969) and also containing C. cantharellus (Louwye et al., 2020a, this volume). The base of the main mass of the Berchem Formation in the Antwerp Campine boreholes is based on borehole data discussed in Louwye et al. (2020a, this volume) and Munsterman \& Deckers (2020, this volume). The biozone of the Zonderschot Sand is from Louwye et al. (2020a, this volume) but the precise lithological transition from the Zonderschot Member to the Antwerpen Member remains unknown.

\section{Limburg Campine}

All data are based on Louwye et al. (2020a, this volume). The slightly diachronic boundary between the Houthalen marine Sand and the Genk Sand is reflected in the occurrence of the $L$. truncatum zone in both the top of the Houthalen Sand and the base of the Genk Sand. The position and the names of the gravels in the Genk Member are from Matthijs (1999). The Kikbeek lignite is a name given in Beerten et al. (2018). Dashed lines indicate uncertain limits of the Opgrimbie glass sand facies in the Genk Member.

\section{Brabant}

The lithostratigraphic data are from outcrops in East Brabant (named Bolderberg sand in Gullentops \& Vandenberghe, 2001) and for Brussels from de Heinzelin (1963a). The uncertainties of the boundaries reflect the limited amount of control data available.

\section{Roer Valley Graben}

Data are from the Molenbeersel and Maaseik boreholes. The chronostratigraphic position of the underlying Voort and Someren Members of the Veldhoven Formation is based on the Molenbeersel borehole and discussed in the Legend Stratigraphic Table Oligocene to Miocene. The chronostratigraphic position of the overlying Diest Formation is based on dinoflagellate cyst biostratigraphy and Bolboforma (B.) biostratigraphy (Goolaerts et al., 2020, this volume) discussed in the Legend Stratigraphic Table upper Miocene. Most detail for the upper part is derived from the revision of dinoflagellate cyst and Bolboforma biostratigraphy in the Maaseik borehole (Louwye et al., 2020a, this volume). The thin Bolboforma barren interval is the possible position for a MMU hiatus if it were not representing the Bolboforma subfragoris zone $(11.56 \mathrm{Ma}-10.50 \mathrm{Ma})$. Based on dinoflagellate cyst content the formerly named intervals 'unknown in the Campine' and 'Upper Antwerp Sand' are part of a continuous sedimentation to the top of the Genk Member.

The Genk Member is recognised in the Molenbeersel borehole by its log signature as a lignite-bearing quartz sand and is equivalent to the Dutch Heksenberg Member. The glauconitebearing section above it in the Molenbeersel borehole consists of the newly proposed Molenbeersel member (Louwye et al., 2020a, this volume) and the Diest Formation. The former unit is considered equivalent to the Dutch Vrijherenberg Member and the boundary with overlying Diest Formation is in the top of the M11 close to the M12 biozone (see for details Deckers \& Munsterman, 2020). Therefore, in the Table, the base of the Diest Formation in the Molenbeersel borehole is placed at the same level as the base of the Deurne-Dessel microfossil-bearing sand in the Maaseik borehole. In previous stratigraphic practice, all glauconitic sands down to the top of the Genk-Heksenberg Formation were included in the Breda Formation. According to Munsterman et al. (2020) the Vrijherenberg Member is now included in the Groote Heide Formation between the EMU (Early Miocene Unconformity) and MMU whereas Louwye et al. (2020a, this volume) suggest to include the Molenbeersel member in the Bolderberg Formation. The large-scale deformations in the Heksenberg Member are seismically derived after Deckers (2015). Biostratigraphic constraints for the Houthalen Formation are limited (Louwye et al., 2020a, this volume).

\section{The upper Miocene Stratigraphic Table (Fig. 3)}

The stratigraphic positions of the top of the underlying Berchem and Bolderberg Formations and the base of the overlying Pliocene units are given in the legends of corresponding lower and middle Miocene and Pliocene Stratigraphic Tables. The Diest Formation, the Kasterlee Formation and the Roer Valley Graben area are discussed separately. The dinoflagellate zonations (de V \& N: de Verteuil \& Norris, 1996; D \& P: Dybkjær \& Piasecki, 2010) are given together with the relevant Bolboforma zones (after King, 2016).

The lithostratigraphic terminology of the units of the Diest Formation in the Campine is discussed in Houthuys et al. (2020, this volume) and thickness data are from reference boreholes and from literature. The stratigraphy of the Deurne and Borsbeek units in Antwerp is from Goolaerts et al. (2020, this volume). The Bolboforma stratigraphy follows King (2016) and determines the base of the Diest Formation with $B$. metzmacheri reported from the Deurne and Dessel Members (Willems, 1976; Laga \& De Meuter 1972; Goolaerts et al., 2020, this volume). The Dessel Member has not been reported east of the Mol- 


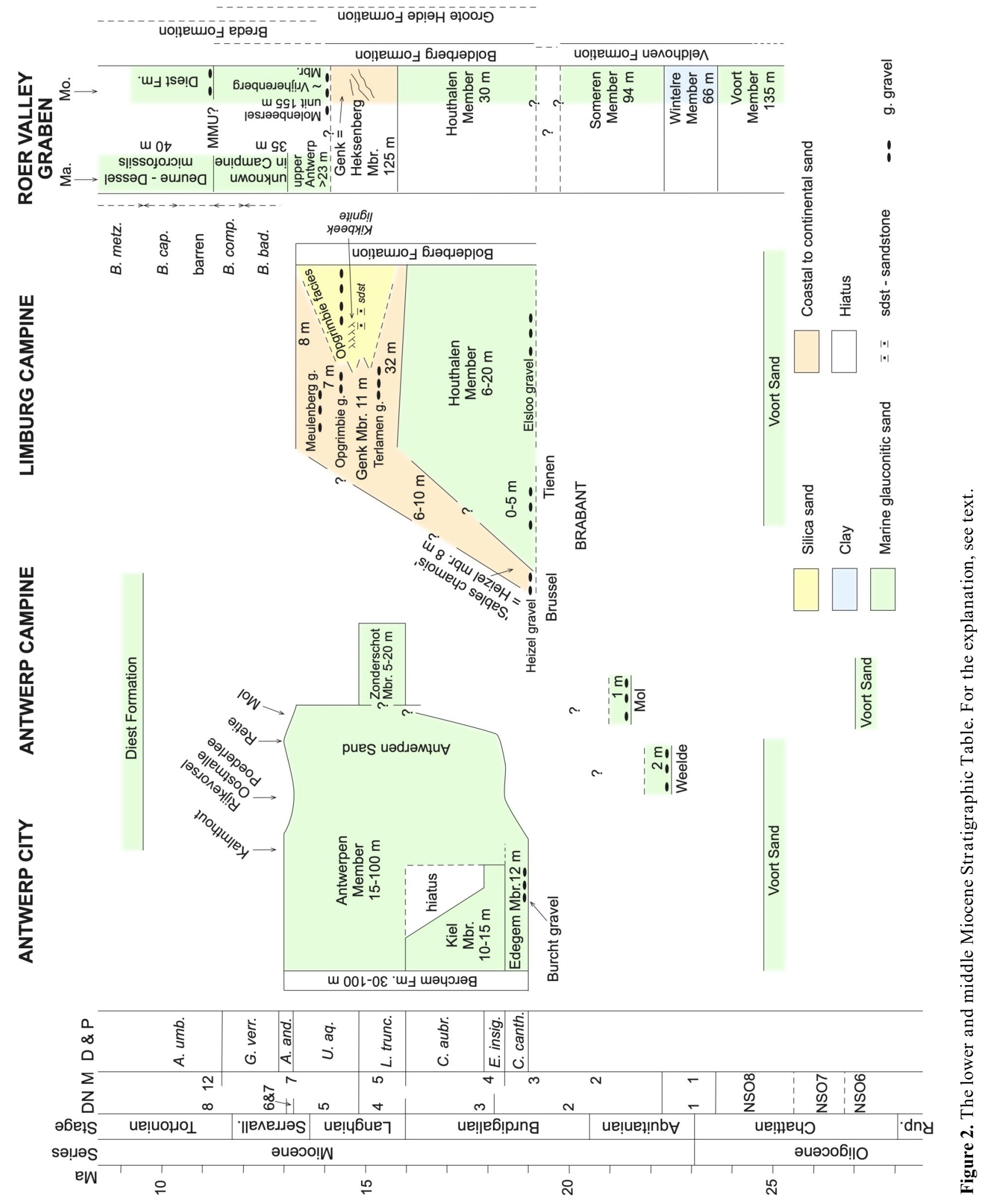


Dessel area by Gullentops \& Vandenberghe (1995, profile 1 fig. 30). In the Limburg Campine area the base of the Campine Diest sand, without underlying Dessel Sand, is definitely within dinoflagellate cyst zone $A$. umbraculum and tentatively also placed at the base of the $B$. metzmacheri Zone. Note that, if the Bolboforma zonation is followed, the glauconite radiometric age reported as probably reliable in Vandenberghe et al. (2014) for the base of the Diest Formation in the ON-Dessel 5 borehole (GSB 031W0370/DOV ON-Dessel-5) also has to be influenced by reworked pellets. Within the fine-grained Dessel Sand Member a lower carbonate holding part and an upper part without carbonate are distinguished but chronostratigraphic information about the boundary between both parts is missing and therefore only tentatively indicated as a dotted line. Aside the calcareous microfossil Bolboforma, the chronostratigraphic range of the Diest Formation in the Campine is further constrained by the dinoflagellate cyst literature data summarised in Vandenberghe et al. (2014, fig. 3) with the addition that $A$. umbraculum Zone (in DN8 Zone) also occurs at the base of the Poederlee borehole (P) (GSB 030W0300/DOV kb16d30wB315). Note that whereas biozone DN10 occurs in a substantial part of the Diest Formation in the western Kalmthout (K) (GSB 006E0110), Oostmalle (O) (GSB 029E0249/DOV kb16d29e$\mathrm{B} 276)$ and Poederlee (P) boreholes and in a minor top part of the Diest Formation in the Retie (R) (GSB 031W0243/DOV kb17d31w-B228), ON-Dessel-5 (D) and Mol-Belchim (M) (GSB 031W0221/DOV kb17d31w-B212) boreholes, the study of the Kasterlee deposits (Vandenberghe et al., 2020, this volume) states that the boundary between the Diest and Kasterlee Formations coincides with the DN9 to DN10 boundary. A clayey and vermiculite containing unit (D4) occurs in the top of the Diest Formation in the Limburg Campine (Adriaens \& Vandenberghe, 2020, this volume).

In the Hageland area, the incision of the deep gully necessarily precedes its infill, but its precise timing and evolution is unknown and therefore indicated by a dashed incision line and question mark. In the Hageland the Dessel Sand is not observed south of the Veerle borehole (V) (GSB 060E0215/DOV kb24d60e-B219) in which it holds dinoflagellate zone DN8 (U. umbraculum); the dinoflagellate barren Hageland Diest sand is considered of similar age in the genetic model of Vandenberghe et al. (2014). Goolaerts et al. (2020, this volume) suggest a possible relationship between the Borsbeek unit in the Antwerp area and the Hageland Dessel sand.

The Hechtel borehole (He) (GSB 047E0192/DOV kb17d47e -B186), without biostratigraphic data is similar in thickness to the nearby Wijshagen borehole (Wij) (GSB 048W0180/DOV kb18d48w-B181) with biostratigraphic control (DN8) and therefore both boreholes are placed near to each other in the table. According to the description by Gulinck (1964a), the clayey D4 facies could be present in the top of the Wijshagen borehole but no clay mineral analyses are available and therefore it is not indicated on the profile. According to the genetic model in Vandenberghe et al. (2014, fig. 13) the Diest Formation at Wijshagen and Neeroeteren could be deposited during both DN8 and DN9, an uncertainty indicated by the question mark. In the Neeroeteren borehole (N) (GSB 064W0234/DOV kb26d64w-B242) the Diest Sand described by Gulinck (1964b) as the Opoeteren facies holds biozone DN9.

Biostratigraphy, thickness and geographical distribution of the Kasterlee Formation and the 'lower Mol' or 'Kasterlee-sensu -Gulinck' unit, including the unnamed sand unit in between both, are discussed in Vandenberghe et al. (2020, this volume). Included are the data on the Hallaar (a), Beerzel (b) and Heistop-den-Berg (c) units in the Kasterlee Formation from Verhaegen et al. (2020, this volume). The type Kasterlee Sand thickness of nearly $20 \mathrm{~m}$ is from the Rees borehole (GSB 017E0399/DOV kb8d17e-B495) in Buffel et al. (2001) and from Laga (1976); the boundary between Diest and Kasterlee Formations in this borehole coincides with the DN9 and DN10 boundary. The 'clayey Kasterlee' unit of the Kasterlee Formation together with the 'lower Mol' or 'Kasterlee-sensuGulinck' unit belong to the same dinoflagellate cyst zone DN10 as does a large part of the Diest Formation in the west. Therefore, question marks are inserted at the lateral transition of the Diest Formation to the Kasterlee Formation and also at the top of the western part of the Diest Formation. Short hiatuses are shown at the transition of the Diest Formation and the 'clayey Kasterlee' unit, and between the latter and the 'lower Mol' or 'Kasterlee-sensu-Gulinck' unit based on the generally observed reworking at the base of the overlying units (Vandenberghe et al. 2020, this volume; Adriaens \& Vandenberghe, 2020, this volume). The question mark between the type Kasterlee Sand and the 'lower Mol' or 'Kasterlee-sensu -Gulinck' reflects the uncertainty of their lateral relationship: a facies evolution transition or an erosive contact (Vandenberghe et al., 2020, this volume).

The stratigraphy of the upper Waubach Member, the Inden Formation and the unit X in the RVG section is from the revised Maaseik borehole (Ma) discussed in Louwye \& Vandenberghe (2020, this volume). Combining revised dinoflagellate zonations (Louwye et al., 2020a, this volume) and Bolboforma data, originally determined by Hooyberghs et al. (2004) and now reinterpreted in the composite stratigraphy of King (2016), allows to improve the chronostratigraphic position of the 'DeurneDessel microfossil association', the 'unknown facies in the Campine' and the 'Upper Antwerp sand' units originally identified in the Maaseik borehole Breda Formation section (Vandenberghe et al., 2005). Assuming that the Bolboformabarren lower part of the 'Deurne-Dessel microfossil association' unit corresponds to the missing Bolboforma subfragoris Zone (dotted vertical line) means that sedimentation in the Roer Valley Graben was not markedly interrupted by the MMU as it was in the Campine. In the Molenbeersel borehole (Mo), presented at the right side in the lower part of the RVG column, Deckers \& Munsterman (2020) have newly identified, below the Diest Sand, the Molenbeersel member probably corresponding in its top to the 'unknown facies in Campine' unit in the Maaseik borehole (left side of the column), and consequently also putting the base of the Diest Sand in the Molenbeersel borehole at the same level. According to these authors (op. cit., fig. 3), the boundary with the underlying quartz sand of the Genk Member occurs within dinoflagellate zone M7 (for a large part DN5) being therefore somewhat older than the top of the Genk Member in the Limburg Campine as determined in Louwye et al. (2020a, this volume). Therefore, its top in the RVG is indicated with a dashed line.

\section{The Pliocene Stratigraphic Table (Fig. 4)}

The biostratigraphic columns are taken from the IGCP-124 project results in the Zanclean-Piacenzian interval (Vinken, 1988, fig. 267) and stretched along the present chronostratigraphic stage boundary ages (ICS chart, 2020). These IGCP-124 biostratigraphic subdivisions are also used in the Pliocene studies by Buffel et al. (2001) and Vandenberghe et al. (2000). The regional Reuver-Brunssum stratigraphic positions are from Wong et al. (2007, fig. 13). Reuver A, B, C subdivisions are based on pollen associations by Zagwijn in the RVG area (see also de Mulder et al., 2003, fig. 111 and Westerhoff, 2009, fig. 5.7). The Kieseloolite Formation includes at its top the Reuver Clay (TNO-GDN, 2020).

The chronostratigraphic position of the Kattendijk Formation is based on a combination of IGCP-124 data and 


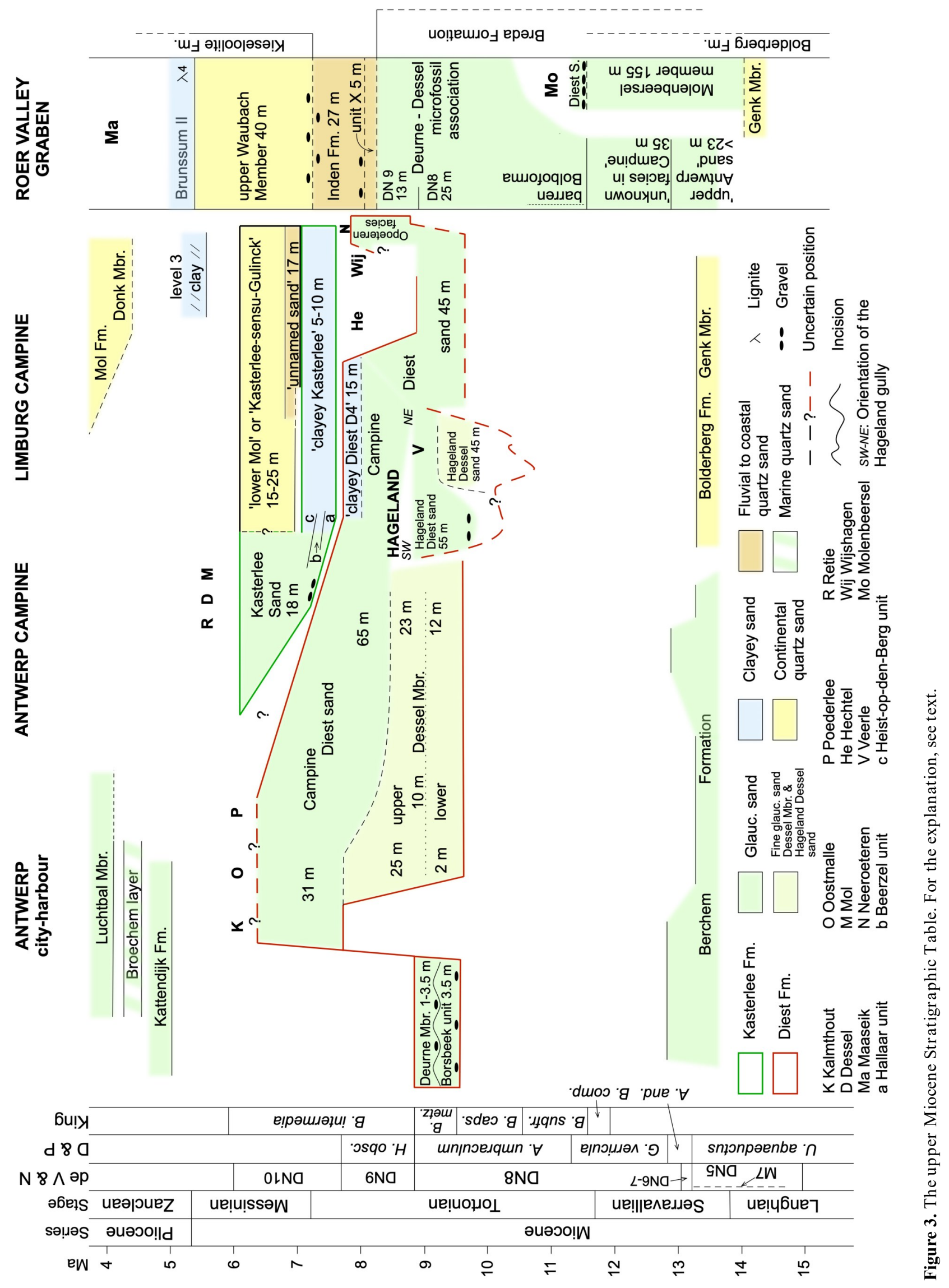


dinoflagellate cyst ranges in Deckers \& Louwye (2020, this volume) and its thickness data are from Deckers \& Louwye (2020, this volume) and from profiles by Laga (1976). Data in the Waasland area are from Laga (1971).

The estimated chronostratigraphic position of the less than $25 \mathrm{~cm}$ thick Broechem concretion layer, occurring intercalated between the Kattendijk Sand and the Luchtbal Member, is in line with the mollusc similarity with the Coralline Crag (Wesselingh et al., 2020, this volume). The Broechem layer is particular as it is a marine quartz sand unlike the glauconitic marine sand of the under- and overlying formations.

IGCP-124 biostratigraphic data of the Luchtbal Member are in line with the 4.04 Ma sequence boundary at its base proposed by De Schepper et al. (2009) and its thickness is from Louwye et al. (2020b, this volume) and from profiles in Laga (1976).

The chronostratigraphic positions of Oorderen, Kruisschans, Merksem and Zandvliet Members of the Lillo Formation are in line with the dinoflagellates ages reported in Louwye et al. (2020b, this volume) and with the IGCP-124 biostratigraphic data; the Amerika dock gravel at the base of the Kruisschans Member follows de Heinzelin (1963b) and the Grobbendonk clay layer as correlating with the Kruisschans Member follows Vandenberghe et al. (2000). The CPT B subdivision in the Table marks the clayey middle part of a threefold CPT subdivision of the Lillo Formation by Deckers et al. (2020, this volume) and therefore put along the clayey top part of the Oorderen Member and the Kruisschans Member. The chronostratigraphy, thickness and geometrical position of the Poederlee Formation is presented as discussed in Louwye et al. (2020b, this volume); the Heieinde data are from Buffel et al. (2001). The vertical hatched line between the Poederlee Sand and the Lillo Formation indicates that the exact transition is not observed but the Poederlee Sand extension to the west is limited.

The geometry of the Merksplas and Mol Formations with the Rees facies at their transition, is figured as discussed in Louwye et al. (2020b, this volume). The palynologies of the Merksplas Formation and of the lignites of the Mol Formation are similar and considered Reuver B (Louwye et al., 2020b, this volume). The thickness of the Merksplas Formation is from profiles in Laga (1976) and of the Mol Formation from profiles in Vandenberghe et al. (2020, this volume, figs 2, 5).

No biostratigraphic control exists regarding the base of the Donk Sand Member. It is assumed in the Table that the westward extension of the fluviatile sand out of the RVG occurred stepwise in line with subsidence pulses in the Campine area creating also accommodation for marine sediments in the west such as the deposition of the Broechem layer and the Luchtbal Member and the start of Oorderen Member, with a next pulse bringing the Mol Sand into contact with the Poederlee Sand and a final pulse allowed even further westward extension of the fluviatile facies such as the Rees facies and the Merksplas Formation overstepping at that moment the marine deposits. In the Limburg Campine subsurface the clay layer capping the 'lower Mol' or 'Kasterlee-sensu-Gulinck' (level 3 on fig. 5 in Vandenberghe et al., 2020, this volume) is tentatively equated with the lowermost Brunssum clay (Louwye \& Vandenberghe, 2020, this volume).

All data in the RVG are from the Maaseik borehole (Vandenberghe et al., 2020, this volume; Louwye \& Vandenberghe, 2020, this volume). The upper Waubach Member is top Miocene (Louwye et al., 2020b, this volume). Following Wong et al. (2007, fig. 13), the complex with Brunssum clays and Pey Sand is the regional Brunssumian stage and hence Zanclean. The regional stage Reuverian is made up of all Pliocene deposits above the Brunssum Complex following Wong et al. (2007, fig. 13). Dricot, cited in Gullentops \& Vandenberghe (1995, p. 27), considers the Russendorp Lignite flora different from the Maat Lignite flora but both lignites as Reuver. Vandenberghe et al. (2005) consider the upper part of the palynology A interval similar to the Mol Sand lignites and the top of palynology A as about equivalent to the boundary between 'Scaldisien' and 'Merksemien' sensu de Heinzelin (1963b) which is within Reuver A; the palynology B zone is considered as Reuver $\mathrm{C}$ in Vandenberghe et al. (2005). The palynology in the Kruisschans and Merksem Members could be interpreted as Reuver B (Louwye et al., 2020b, this volume). These published attributions to substages A, B, C within the Reuver regional stage can only be considered as tentative. Besides, as these substages are based on pollen associations they do not have a direct chronostratigraphic meaning but rather point to changes in the vegetation cover (see also Kemna \& Westerhoff, 2007). Note that the Reuver clay bed in the top of the Maaseik borehole section (Vandenberghe et al., 2005) forms the top of the Kieseloolite Formation according to Westerhoff (2009, fig. 5.7) and TNO-GDN (2020). At the top of the RVG section a question mark indicates the possible presence of the Quaternary already in the top of the Shinveld /Jagersborg Sand; Shinveld is the name used in the Dutch nomenclature (Wong et al., 2007) whereas Vanhoorne et al. (1999) used the name Jagersborg. No obvious hiatuses are demonstrated in the Pliocene section in the RVG.

The present topographic difference between the Campine Plateau and the eroded sand West of it makes that the hiatus with the Quaternary deposits is probably somewhat larger in the west, indicated with the hatched line at the top and the question marks.

\section{Outlook for future research}

Understanding the Neogene stratigraphy and its palaeogeographical evolution has considerably progressed during the last decennia but challenging issues remain.

The surprising identification of Aquitanian sediments in the Campine needs confirmation in other boreholes straddling the Oligocene-Miocene boundary. Undoubtedly the way dinoflagellate cyst analyses are used amongst researchers of the North Sea Basin needs to become more comparable between each other and further integration is needed. Stratigraphic issues could definitely benefit from a more combined use of different fossil groups for stratigraphic zonation. Such an approach was successfully used in the IGCP-124 North Sea correlation project leading to a regional stratigraphic zonation. The modern progress in dinoflagellate stratigraphy should not develop alongside other older or new biostratigraphic work as demonstrated by the application of the Bolboforma zonation since King (2016) proved their reliability in a comprehensive North Sea Basin stratigraphy. An example of the need for better stratigraphic resolution is the occurrence of the same dinoflagellate cyst zone characterising as well the western part of the prograding mass of Diest Campine sand, as the Kasterlee Sand, the clayey Kasterlee unit and the lower part of the lower Mol or Kasterlee-sensu-Gulinck unit.

The Burdigalian-Langhian biostratigraphy of the Members of the Berchem and Bolderberg Formations has improved. Biostratigraphy data on the Houthalen Sand are still too limited and the meaning of the Genk Member subdivisions described during the geological mapping is not yet understood and neither is the precise geometrical relation of the Opgrimbie silica sand facies in it. A palynological comparison of the Kikbeek lignite in the latter with the Morkhoven and Frimmersdorf lignite horizons of the Lower Rhine Ville Formation is still lacking. An integrated sedimentological, mineralogical and micropalaeontological study of the regional palaeogeographical evolution of both the Berchem and Bolderberg Formations would be a logical follow-up investigation. 

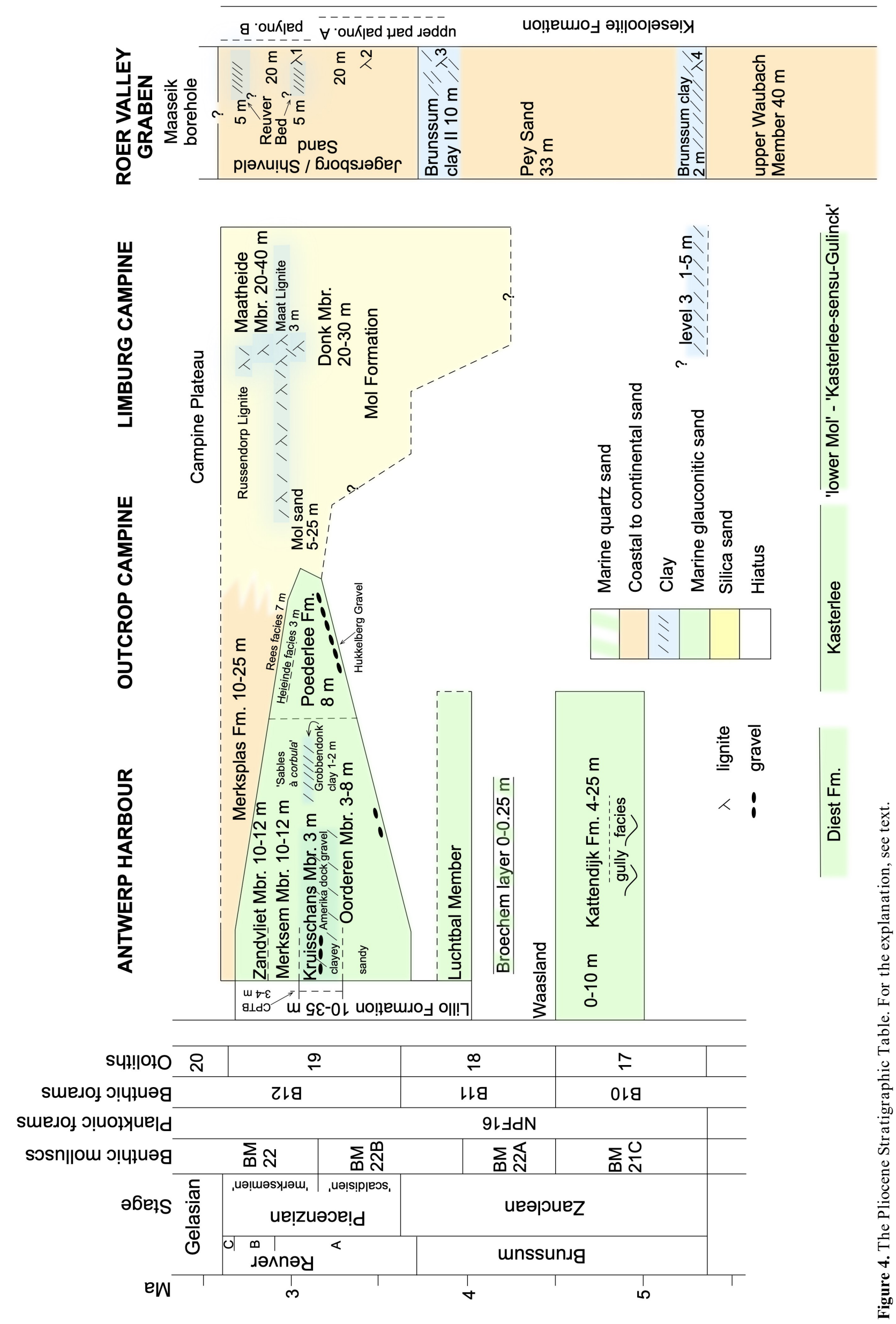
Several studies of the Diest Formation and its members have led to the proposition of genetic models. Nevertheless, several of the proposed elements in these models remain debatable and will need verification. The present review of the models has the advantage for follow-up studies to address more efficiently crucial issues trying to confirm or invalidate a model or parts of it. The sedimentological understanding of the newly introduced Borsbeek unit, the Deurne and the Dessel Members with respect to each other and to the Campine Diest sand probably is still hiding some surprises, not to speak of their relationship with the Hageland Diest and Dessel sand. The precise lateral transition from the Diest Campine sand to the unit $\mathrm{X}$ and the Inden Formation in the RVG needs to be documented in more detail. Besides, the complete continental Pliocene section in the Belgian RVG needs a better chronostratigraphic characterisation.

Understanding the regional palaeogeographical evolution and in particular the exact nature of the contacts between the 'clayey Kasterlee' Formation and the 'lower Mol' or 'Kasterleesensu-Gulinck' and the Mol Formation, will require additional biostratigraphic control, sedimentological and mineralogical analyses and more detailed lateral correlations by for example CPT-type investigations. Also, the nature of the lateral transition of the previously mentioned stratigraphic units with the stratotype Kasterlee and the Poederlee Formations is not well understood. The same holds for the lateral evolution of the typical Mol Sand towards the Merksplas Sand and the presence of transition facies between. Even more important is that more detailed palynology is needed to precisely characterise the Pliocene to Pleistocene transition.

In the Neogene studies, palaeobathymetric interpretation of macrofossils and microfossils is generally missing. Also remains the barely addressed geochemical issue of the origin of the enormous quantities of iron enclosed in unusually abundant glauconite pellets apparently formed only at a few specific stratigraphic levels and more generally reworked than thought before. Related to the iron geochemistry in the Neogene strata, is the poorly studied presence of siderite horizons and concretions often described in sections. Another geochemical element that needs more attention is phosphorus, occurring obviously in the numerous levels with bone fragments but also in diagenetic vivianite and apatite cementations.

The existing wealth of data already collected on the Neogene geology of Belgium should not make us forget that to solve existing uncertainties and unknowns and to improve our existing models, investment remains necessary in the collection of new and always better quality data. By its nature, regional geology is necessarily based on partial datasets and their completion is seldom finished. Field data are the primary data requiring investment in the study of temporary excavations and outcrops and in obtaining information from new boreholes. Conservation and retrieval facilities for cores and samples should be maintained with easy access for researchers.

Analyses addressing sedimentology, biostratigraphy, mineralogy and other scientific disciplines, should be done together at the same time on the same quality samples. Progress in analytical techniques should complement classical sedimentpetrological methods by studying detailed properties of specific minerals leading to their specific provenance areas. Analytical methods now allow to obtain grain-size distributions combined with automated shape analysis potentially upgrading the latter to a more common analysis and thereby exploiting its sedimentological information (Blott \& Pye, 2008). Also, SEM investigation of quartz grains is underexploited in studies of the Neogene in Belgium although such surface textures could be of help in understanding transport and depositional history (Vos et al., 2014).

Studied sections should preferably also have stratigraphically well calibrated good quality geophysical borehole logs which will continue to be an invaluable source for correlation work in the area. Once better stratigraphically calibrated this could also become true for Cone Penetration Testing, the use of which is recommended. Improvement of the stratigraphic calibration of geophysical and geotechnical log signals requires teamwork. Surface geophysical methods such as Ground Penetrating Radar and shallow reflection seismic surveys are not commonly used today in Neogene studies but could be considered to investigate specific issues at relatively shallow depths.

The updated Neogene database is offering a powerful tool for data retrieval. It goes beyond saying that a database without continuous updating rapidly becomes useless. The data in the central database should not only consist of the interpreted stratigraphic boundaries forming the base for geographical distribution studies and for building 3D models but also contain analytical results of all nature. The common availability of software for interpretation, statistical analysis or graphic presentations of the analytical data requires that the data can be made available for use in such software programs. This can require reworking of old data when acquired before automated instrumentation became available and when the presentation of data was done in a different way as is for example the case with the wealth of old grain-size data that should be valorised.

All the above suggestions are a plea for teamed project and collaborative research around specific topics. Obviously, a good balance is required between the common research goal and the individual creativity and curiosity; too fragmented or dispersed research needs to be avoided. A good understanding between research institutes, university laboratories, private earth science and technology-based companies and geological surveys is the basis for such collaborative research. The National Stratigraphic Subcommission for the Paleogene and Neogene could become the natural platform for such coordination aside its primordial task of establishing a scientifically sound and still practical stratigraphy and thereby officialising stratigraphic nomenclature, a prerequisite for communication amongst all users of subsurface data. It goes indeed without saying that the many lithostratigraphic units, formal and informal, redefined and proposed in this Neogene volume need a further thorough discussion in the National Commission for Stratigraphy with some necessary regrouping of units aiming at presenting a scientifically sound and still practical Neogene stratigraphy.

\section{Acknowledgements}

We are grateful that Geologica Belgica has accepted to publish this thematic volume on the Neogene of Belgium. Annick Anceau, editor of Geologica Belgica is thanked very sincerely for her extensive and rigorous work on all the manuscripts and the layout of the thematic volume. Marleen De Ceukelaire of the Geological Survey of Belgium and Katrien De Nil of the Flemish public administration Subsurface Team are thanked for continuously providing information to authors during the project and for composing an exemplary database of the Neogene of Belgium. All authors are thanked for their considerable and well -appreciated effort in wrapping up their research of past times. All reviewers are thanked for their constructive help in improving the quality of the manuscripts: three anonymous reviewers, Beerten, K., Busschers, F., Dusar, M., Dybkjær, K., El Albani, A., Elsen, J., Gurdebeke, P., Harding, I., Houthuys, R., Louwye, S., Marquet, R., Matthijs, J., Menkovic, M., Munsterman, D., Prinz, L., Reynaud, J.-Y., Rogiers, B., Salamon, M., Speijer, R., Stassen, P., Steurbaut, E., Van Alboom, G., van de Graaf, H., Vandenberghe, N., van der Voort, J., Van Lancker, V., van Putten, G., Van Ranst, E., Van Simaeys, S., Verhaegen, J., von Eynatten, H., Ward, D., Wesselingh, F. 


\section{References}

Adriaens, R. \& Vandenberghe, N., 2020. Quantitative clay mineralogy as a tool for lithostratigraphy of Neogene Formations in Belgium: a reconnaissance study. Geologica Belgica, 23/3-4, this volume. https://doi.org/10.20341/gb.2020.018

Beerten, K., Dreesen, R., Janssen, J. \& Van Uytven, D., 2018. The Campine Plateau. In Demoulin, A. (ed.), Landscapes and Landforms of Belgium and Luxemburg. Springer, Cham, World Geomorphological Landscapes, 193-214. https:// doi.org/10.1007/978-3-319-58239-9 12

Blott, S.J. \& Pye, K., 2008. Particle shape: a review and new methods of characterization and classification. Sedimentology, 55, 31-63. https://doi.org/10.1111/j.1365-3091.2007.00892.x

Borremans, M. (ed.), 2015. Geologie van Vlaanderen. Academia Press, Gent, $491 \mathrm{p}$

Buffel, P., Vandenberghe, N., Goolaerts, S. \& Laga, P., 2001. The Pliocene in 4 boreholes in the Turnhout area (North-Belgium): the relation with the Lillo and Mol Formations. Aardkundige Mededelingen, 11, 1-9.

Buffel, Ph., Van Barel, L. \& Gullentops, F., 2002. Geologische kaart van België, Vlaams Gewest: Turnhout-Meerle, kaartblad 8-2. 1/50 000 Belgische Geologische Dienst en Afdeling Natuurlijke Rijkdommen en Energie, Brussel. https://www.vlaanderen.be/ publicaties/tertiairgeologische-kaart-van-belgie-kaartblad-2-8Meerle-Turnhout, accessed 02/12/2020.

Coccioni, R., Montanari, A., Bice, D., Brinkhuis, H., Deino, A., Frontalini, F., Lirer, F., Maiorano, P., Monechi, S., Pross, J., Rochette, P., Sagnotti, L., Sideri, M., Sprovieri, M., Tateo, F., Touchard, Y., Van Simaeys, S. \& Williams, G.L., 2018. The Global Stratotype Section and Point (GSSP) for the base of the Chattian Stage (Paleogene System, Oligocene Series) at Monte Cagnero, Italy. Episodes, 41/1, 17-32. https://doi.org/10.18814/epiiugs/2018/ v41i1/018003

Deckers, J., 2015. Middle Miocene mass transport deposits in the southern part of the Roer Valley Graben. Marine and Petroleum Geology, 66/4, 653-659. https://doi.org/10.1016/ j.marpetgeo.2015.07.006

Deckers, J. \& Louwye, S., 2020. The architecture of the Kattendijk Formation and the implications on the early Pliocene depositional evolution of the southern margin of the North Sea Basin. Geologica Belgica, 23/3-4, this volume. https://doi.org/10.20341/gb.2020.017

Deckers, J. \& Munsterman, D., 2020. Middle Miocene depositional evolution of the central Roer Valley Rift System. Geological Journal, 55/9, 6188-6197. https://doi.org/10.1002/gj.3799

Deckers, J., Vernes, R.W., Dabekaussen, W., Den Dulk, M., Doornenbal, J.C., Dusar, M., Hummelman, H.J., Matthijs, J., Menkovic, A., Reindersma, R.N., Walstra, J., Westerhoff, W.E. \& Witmans, N., 2014. Geologisch en hydrogeologisch 3D model van het Cenozoïcum van de Roerdalslenk in Zuidoost-Nederland en Vlaanderen (H3O-Roerdalslenk). Studie uitgevoerd door VITO, TNO-Geologische Dienst Nederland en de Belgische Geologische Dienst in opdracht van de Afdeling Land en Bodembescherming, Ondergrond, Natuurlijke Rijkdommen van de Vlaamse overheid, de Afdeling Operationeel Waterbeheer van de Vlaamse Milieumaatschappij, de Nederlandse Provincie Limburg en de Nederlandse Provincie Noord-Brabant, VITO en TNO-Geologische Dienst Nederland. VITO-rapport 2014/ETE/R/1, 205 p. https:// archief.onderzoek.omgeving.vlaanderen.be/Onderzoek-2314144, accessed 02/12/2020.

Deckers, J., De Koninck, R., Bos, S., Broothaers, M., Dirix, K., Hambsch, L., Lagrou, D., Lanckacker, T., Matthijs, J., Rombaut, B., Van Baelen, K. \& Van Haren, T., 2019. Geologisch (G3Dv3) en hydrogeologisch (H3D) 3D-lagenmodel van Vlaanderen. Studie uitgevoerd in opdracht van het Vlaams Planbureau voor Omgeving, departement Omgeving en de Vlaamse Milieumaatschappij. VITO, Mol, VITO-rapport, 2018/RMA/R/1569, 286 p. https:// researchportal.be/en/publication/geological-g3dv3-and-hydrogeologicalh3d-3d-layer-model-flanders, accessed 02/12/2020.

Deckers, J., Louwye, S. \& Goolaerts, S., 2020. The internal division of the Pliocene Lillo Formation: correlation between Cone Penetration Tests and lithostratigraphic type sections. Geologica Belgica, 23/34, this volume. https://doi.org/10.20341/gb.2020.027

de Heinzelin de Braucourt, J., 1955a. Deuxième série d'observations stratigraphiques au Kruisschans. Coupes de l'écluse Baudouin. I. Analyse stratigraphique. Bulletin de l'Institut royal des Sciences naturelles de Belgique, Sciences de la Terre, 31/66, 1-29.

de Heinzelin de Braucourt, J., 1955b. Deuxième série d'observations stratigraphiques au Kruisschans. Coupes de l'écluse Baudouin. 2 : Conclusions. Bulletin de l'Institut royal des Sciences naturelles de Belgique, Sciences de la Terre, 31/66, 14 p.

de Heinzelin, J., 1963a. Compte-rendu des excursions : Point 4 HeiselWemmel. In de Heinzelin, J. \& Tavernier, R., Symposium sur la stratigraphie du Néogène nordique. Société belge de Géologie, Mémoires in- $8^{\circ}, 6,195-197$.

de Heinzelin, J., 1963b. Carte et coupe d'ensemble de région anversoise. In de Heinzelin, J. \& Tavernier, R., Symposium sur la stratigraphie du Néogène nordique. Société belge de Géologie, Mémoires in- $8^{\circ}$, 6, 247-248.

de Heinzelin J. \& Tavernier R. (eds), 1963. Symposium sur la stratigraphie du Néogène nordique. Société belge de Géologie, Mémoires in- $8^{\circ}, 6,248 \mathrm{p}$

De Keyzer, M., Dewyngaert, N. \& Schepers D., 2019. Visie DOV 2030. Department of Environment \& Spatial Development, Brussels, 45 p. https://archief.onderzoek.omgeving.vlaanderen.be/Onderzoek2113731, accessed 02/12/2020.

De Man, E., Van Simaeys, S., Vandenberghe, N., Harris, W.B. \& Wampler, J.M., 2010. On the nature and chronostratigraphic position of the Rupelian and Chattian stratotypes in the southern North Sea basin. Episodes, 33/1, 3-14. https://doi.org/10.18814/ epiiugs/2010/v33i1/002

De Meuter, F. \& Laga, P., 1976. Lithostratigraphy and biostratigraphy based on benthic foraminifera of the Neogene deposits of Northern Belgium. Bulletin van de Belgische Vereniging voor Geologie, 85/4, 133-152.

de Mulder, E.F.J., Geluk, M.C., Ritsema, I., Westerhoff, W.E. \& Wong, T.E., 2003. De ondergrond van Nederland. Wolters-Noordhoff, Groningen/Houten, 379 p.

De Nil, K., De Koninck, R., Corluy, J., De Rouck T. \& Van Damme, M., 2018. Explore the subsurface of Flanders with the Virtual Borehole. Abstracts of the 6th International Geologica Belgica Meeting. 12-14 September 2018, Leuven, Belgium. https:// ees.kuleuven.be/gb2018/abstracts/, accessed 02/12/2020.

De Nil, K., De Ceukelaire M. \& Van Damme M., 2020. A reference dataset for the Neogene lithostratigraphy in Flanders, Belgium. Geologica Belgica, 23/3-4, this volume. https://doi.org/10.20341/ gb.2020.021

De Schepper, S., Head, M. J. \& Louwye, S., 2009. Pliocene dinoflagellate cyst stratigraphy, palaeoecology and sequence stratigraphy of the Tunnel-Canal Dock, Belgium. Geological Magazine, 146/1, 92-112. https://doi.org/10.1017/ S0016756808005438

de Verteuil, L. \& Norris, G. 1996. Miocene dinoflagellate stratigraphy and systematics of Maryland and Virginia. Micropaleontology, 42, Supplement, 1-172. https://doi.org/10.2307/1485926

Doppert, J.W.C., Laga, P. \& De Meuter, F., 1979. Correlation of the biostratigraphy of marine Neogene deposits, based on benthic foraminifera, established in The Netherlands and Belgium. Mededelingen Rijks Geologische Dienst, 31/2, 1-8.

Dusar, M. \& Vandenberghe, N., 2020. Upper Oligocene lithostratigraphic units and the transition to the Miocene in North Belgium. Geologica Belgica, 23/3-4, this volume. https:// doi.org/10.20341/gb.2020.009

Dybkjær, K. \& Piasecki, S., 2010. Neogene dinocyst zonation for the eastern North Sea Basin, Denmark. Review of Palaeobotany and Palynology, 161/1-2, 1-29. https://doi.org/10.1016/ j.revpalbo.2010.02.005

Everaert, S., Munsterman, D., De Schutter, P., Bor, T., Bosselaers, M. Van Boeckel, J., Cleemput, G. \& Bor, T.J. 2020. Stratigraphy and palaeontology of the lower Miocene Kiel Sand Member (Berchem Formation) in temporary exposures in Antwerp (northern Belgium). Geologica Belgica, 23/3-4, this volume. https://doi.org/10.20341/ gb. 2020.025

Fourmarier, P. (ed.), 1954. Prodrome d'une description géologique de la Belgique. Société géologique de Belgique, Liège, $826 \mathrm{p}$.

Geets, S. \& De Breuck, W. 1991. De zware-mineraleninhoud van Belgische mesozoïsche en cenozoïsche afzettingen. Neogeen. Natuurwetenschappelijk Tijdschrift, 73, 3-37.

Goolaerts, S., De Ceuster, J., Mollen, F.H., Gijsen, B., Bosselaers, M., Lambert, O., Uchman, A., Van Herck, M., Adriaens, R., Houthuys, R., Louwye, S., Bruneel, Y., Elsen, J. \& Hoedemakers, K., 2020. The upper Miocene Deurne Member of the Diest Formation revisited: unexpected results from the study of a large temporary outcrop near Antwerpen International Airport, Belgium. Geologica Belgica, 23/3-4, this volume. https://doi.org/10.20341/gb.2020.011

Gulinck, M. 1964a. Borehole description Wijshagen. Archieven Belgische Geologische Dienst. http://collections.naturalsciences.be/sshgeology-archives/arch/048w/048w0180.txt, accessed 02/12/2020.

Gulinck, M. 1964b. Borehole description Neeroeteren. Archieven Belgische Geologische Dienst. http://collections.naturalsciences.be/sshgeology-archives/arch/064w/064w0234.txt, accessed 02/12/2020.

Gulinck, M. 1969. Borehole description Essen-Kalmthout. Archieven Belgische Geologische Dienst. http://collections.naturalsciences.be/ ssh-geology-archives/arch/006e/006e0110.txt, accessed 02/12/2020. 
Gullentops, F., 1963. Etude de divers facies quaternaires et tertiaires dans le Nord et l'Est de la Belgique. Excursion O-P, 6 e Congrès International de Sédimentologie, Belgique et Pays-Bas, 1963, 20 p.

Gullentops, F., 1973. Grainsize and mineralogy of Miocene glass-sands of Maasmechelen, Belgian Limburg. Mededelingen Rijks Geologische Dienst, Nieuwe Serie, 23, 1972-1973, 25-34.

Gullentops, F. \& Vandenberghe, N., 1995. Toelichtingen bij de geologische kaart van België, Vlaams Gewest: kaartblad 17, Mo [1/50 000]. Belgische Geologische Dienst en Ministerie van de Vlaamse Gemeenschap, Afdeling Natuurlijke Rijkdommen en Energie, Brussel, 65 p.

Gullentops, F. \& Vandenberghe, N., 2001. Toelichtingen bij de geologische kaart van België, Vlaams Gewest: kaartblad 32, Leuven [1/50 000]. Belgische Geologische Dienst en Ministerie van de Vlaamse Gemeenschap, Afdeling Natuurlijke Rijkdommen en Energie, Brussel, 77 p.

Hager, H., Vandenberghe, N., van den Bosch, M., Abraham, M., von der Hocht, F., Rescher, K., Laga, P., Nickel, E., Verstraelen, A., Leroi, S. \& van Leeuwen, R.J.W., 1998. The geometry of the Rupelian and Chattian depositional bodies in the Lower Rhine district and its border area: implications for Oligocene lithostratigraphy. Bulletin of the Geological Society of Denmark, 45, 53-62.

Hooyberghs, H., Wouters, K. \& Spiegler, D., 2004. Marine Miocene deposits in the Maaseik well $49 \mathrm{~W} / 220$ in eastern Belgium: biostratigraphy by means of various microfossil groups. Netherlands Journal of Geosciences / Geologie en Mijnbouw, 83/1, 39-46. https://doi.org/10.1017/S0016774600020448

Houthuys, R., 2011. A sedimentary model of the Brussels Sands, Eocene, Belgium. Geologica Belgica, 14, 55-74.

Houthuys, R., Adriaens, R., Goolaerts, S., Laga, P., Louwye, S., Matthijs, J., Vandenberghe, N. \& Verhaegen, J., 2020. The Diest Formation: a review of insights from the last decades. Geologica Belgica, 23/3-4, this volume. https://doi.org/10.20341/gb.2020.012

ICS chart, 2020. International Chronostratigraphic Chart, v 2020/03. International Commission on Stratigraphy. https://stratigraphy.org/ ICSchart/ChronostratChart2020-03.pdf, accessed 02/12/2020.

Jacobs, P., De Ceukelaire, M., Sevens, E. \& Verschuren, M., 1993. Philosophy and methodology of the new geological map of the Tertiary formations, Northwest Flanders, Belgium. Bulletin de la Société belge de Géologie, 102/1-2, 231-241.

Kemna, H.A. \& Westerhoff, W.E., 2007. Remarks on the palynologybased chronostratigraphical subdivision of Pliocene terrestrial deposits in NW-Europe. Quaternary International, 164-165, 184196. https://doi.org/10.1016/j.quaint.2006.10.017

King, C., 2016. A revised correlation of Tertiary rocks in the British Isles and adjacent areas of NW Europe. Gale, A.S. \& Barry, T.L. (eds). Geological Society, London, Special Reports, 27, 1-719. https://doi.org/10.1144/SR27

Laga, P.G., 1971. De Neogene afzettingen van het Waasland (kb. Beveren-Waas). Service géologique de Belgique / Aardkundige Dienst van België, Professional Paper, 1971/7, 11 p.

Laga, P., 1976. Geologische Doorsneden. Archieven Belgische Geologische Dienst. http://collections.naturalsciences.be/sshgeology/geology/profiles-neogeen2020, accessed 02/12/2020.

Laga, P. \& De Meuter, F., 1972. A foraminiferal fauna found in the lower Member of the Diest Formation of borings in the Antwerp Kempen (NE-Belgium). Bulletin de la Société belge de Géologie, de Paléontologie et d'Hydrologie, 81, 211-220.

Laga, P., Louwye, S. \& Geets, S., 2001. Paleogene and Neogene lithostratigraphic units (Belgium). Geologica Belgica, 4/1-2, 135152. https://doi.org/10.20341/gb.2014.050

Laga, P., De Schepper, S., Louwye, S. \& Herman, J., 2015. Het Plioceen. In Borremans, M. (ed.), Geologie van Vlaanderen. Academia Press, Gent, 165-175.

Légende de la Carte géologique de la Belgique à l'échelle du $40.000 \mathrm{e}, 1909$. Ministère de l'Industrie et du Travail, Direction générale des Mines, Commission géologique de Belgique - Conseil de direction, Bruxelles, $25 \mathrm{p}$.

Légende générale de la Carte géologique détaillée de la Belgique, 1929. Annales des Mines de Belgique, 30/1, 39-80.

Louwye, S., 2000. Dinoflagellate cysts and acritarchs from the Miocene Zonderschot Sands, northern Belgium: stratigraphy and correlation with contiguous areas. Geologica Belgica, 3, 55-65. https:// doi.org/10.20341/gb.2014.023

Louwye, S., 2005. The Early and Middle Miocene transgression at the southern border of the North Sea Basin (northern Belgium). Geological Journal, 40, 441-456. https://doi.org/10.1002/gj.1021

Louwye, S. \& Laga, P., 2008. Dinoflagellate cyst stratigraphy and palaeoenvironment of the marginal marine Middle and Upper Miocene of the eastern Campine area, northern Belgium (southern North Sea Basin). Geological Journal, 43, 75-94. https:// doi.org/10.1002/gj.1103
Louwye, S. \& Vandenberghe, N., 2020. A reappraisal of the stratigraphy of the upper Miocene unit $\mathrm{X}$ in the Maaseik core, eastern Campine area (northern Belgium). Geologica Belgica, 23/3-4, this volume. https://doi.org/10.20341/gb.2014.023

Louwye, S., De Coninck, J. \& Verniers, J., 2000. Shallow marine Lower and Middle Miocene deposits at the southern margin of the North Sea Basin (northern Belgium): dinoflagellate cyst biostratigraphy and depositional history. Geological Magazine, 137, 381-393. https://doi.org/10.1017/s0016756800004258

Louwye, S., Head, M.J. \& De Schepper, S., 2004. Dinoflagellate cyst stratigraphy and palaeoecology of the Pliocene in northern Belgium, southern North Sea Basin. Geological Magazine, 141/3, 353-378. https://doi.org/10.1017/S0016756804009136

Louwye, S., Laga, P. \& Herman, J., 2015. Het Mioceen. In Borremans, M. (ed.), Geologie van Vlaanderen. Academia Press, Gent, 155164.

Louwye, S., Deckers, J., Verhaegen, J., Adriaens, J. \& Vandenberghe, N., 2020a. A review of the lower and middle Miocene of northern Belgium. Geologica Belgica, 23/3-4, this volume. https:// doi.org/10.20341/gb.2020.010

Louwye, S., Deckers, J. \& Vandenberghe, N., 2020b. The Pliocene Lillo, Poederlee, Merksplas, Mol and Kieseloolite Formations in northern Belgium: a synthesis. Geologica Belgica, 23/3-4, this volume. https://doi.org/10.20341/gb.2020.016

Matthijs, J., 1999. Toelichtingen bij de geologische kaart van België, Vlaams Gewest: kaartblad 25, Hasselt [1/50 000]. Belgische Geologische Dienst en Ministerie van de Vlaamse Gemeenschap, Afdeling Natuurlijke Rijkdommen en Energie, Brussel, 104 p.

Matthijs, J., Lanckacker, T., De Koninck, R., Deckers, J., Lagrou, D. \& Broothaers, M., 2013. Geologisch 3D lagenmodel van Vlaanderen en het Brussels Hoofdstedelijk Gewest - versie 2, G3Dv2. Studie uitgevoerd door VITO in opdracht van de Vlaamse overheid, Departement Leefmilieu, Natuur en Energie, Afdeling Land en Bodembescherming, Ondergrond, Natuurlijke Rijkdommen. VITO, Mol, VITO-rapport 2013/R/ETE/43, 21p.

Munsterman, D.K. \& Brinkhuis, H., 2004. A southern North Sea Miocene dinoflagellate cyst zonation. Netherlands Journal of Geoscience / Geologie en Mijnbouw, 83, 267-285. https:// doi.org/10.1017/S0016774600020369

Munsterman, D. \& Deckers, J., 2020. The Oligocene/Miocene boundary in the ON-Mol-1 and Weelde boreholes along the southern margin of the North Sea Basin, Belgium. Geologica Belgica, 23/3-4, this volume. https://doi.org/10.20341/gb.2020.007

Munsterman, D.K., ten Veen, J.H., Menkovic, A., Deckers, J., Witmans, N., Verhaegen, J., Kerstholt-Boegehold, S.J., van de Ven, T. \& Busschers, F.S., 2020. An updated and revised stratigraphic framework for the Miocene and earliest Pliocene strata of the Roer Valley Graben and adjacent blocks. Netherlands Journal of Geosciences, 98, e8. https://doi.org/10.1017/njg.2019.10

Schäfer, A. \& Utescher, T., 2014. Origin, sediment fill, and sequence stratigraphy of the Cenozoic Lower Rhine Basin (Germany) interpreted from well logs. German Journal of Geoscience 165, 287 -314. htttps://doi.org/10.1127/1860-1804/2014/0062

Schneider, H. \& Thiele, S., 1965. Geohydrologie des Erftgebietes. Ministerium für Ernährung, Landwirtschaft und Forsten Land Nordrhein-Westfalen, Düsseldorf, $185 \mathrm{p}$.

Steurbaut, E., 1986. Late Middle Eocene to Middle Oligocene calcareous nannoplankton from the Kallo well, some boreholes and exposures in Belgium and a description of the Ruisbroek Sand Member. Mededelingen Werkgroep Tertiaire en Kwartaire Geologie, 23/2, 49-83.

Tavernier, R., 1954. Le Néogène. In Fourmarier, P. (ed.), Prodrome d'une description géologique de la Belgique. Société géologique de Belgique, Liège, 533-554.

TNO-GDN, 2020. Kiezeloöliet Formatie. In Stratigrafische Nomenclator van Nederland, TNO - Geologische Dienst Nederland. http://www.dinoloket.nl/stratigrafische-nomenclator/ kiezelooliet-formatie, accessed 12/10/2020.

Vandenberghe, N., 2017. Ernest Van den Broeck medallist lecture 2016. Tectonic and climatic signals in the Oligocene sediments of the Southern North-Sea Basin. Geologica Belgica, 20/3-4, 105-123. http://dx.doi.org/10.20341/gb.2017.007

Vandenberghe, N., Laga, P., Steurbaut, E., Hardenbol, J. \& Vail, P.R., 1998. Tertiary sequence stratigraphy at the Southern Border of the North Sea Basin in Belgium. In de Graciansky, P.C., Hardenbol, J., Jacquin, Th. \& Vail, P.R. (eds), Mesozoic and Cenozoic Sequence Stratigraphy of European Basins. SEPM Society for Sedimentary Sedimentology, Special Publication, 60, 119-154. https:// doi.org/10.2110/pec.98.02.0119

Vandenberghe, N., Herman, J., Laga, P., Louwye, S., De Schepper, S., Vandenberghe, J., Bohncke, S.J.P. \& Konert, M., 2000. The stratigraphic position of a Pliocene tidal clay deposit at 
Grobbendonk (Antwerp Province, Belgium). Geologica Belgica, 3/3 -4, 405-417. https://doi.org/10.20341/gb.2014.040

Vandenberghe, N., Van Simaeys, S., Steurbaut, E., Jagt, J.W.M. \& Felder, P.J., 2004. Stratigraphic architecture of the Upper Cretaceous and Cenozoic along the southern border of the North Sea Basin in Belgium. Netherlands Journal of Geosciences, 83/3, 155-171. https://doi.org/10.1017/S0016774600020229

Vandenberghe, N., Laga, P., Louwye, S., Vanhoorne, R., Marquet, R., De Meuter F., Wouters, K. \& Hagemann, H.W., 2005. Stratigraphic interpretation of the Neogene marine-continental record in the Maaseik well (49W0220) in the Roer valley Graben, NE Belgium. Memoirs of the Geological Survey of Belgium, 52, $39 \mathrm{p}$.

Vandenberghe, N., Harris, W.B., Wampler, J.M., Houthuys, R., Louwye, S., Adriaens, R., Vos, K., Lanckacker, T., Matthijs, J., Deckers, J., Verhaegen, J., Laga, P., Westerhoff, W. \& Munsterman, D., 2014. The implications of K-Ar glauconite dating of the Diest Formation on the paleogeography of the Upper Miocene in Belgium. Geologica Belgica, 17, 161-174.

Vandenberghe, N., De Ceukelaire M. \& Welkenhuysen K., 2015. Geologische kaarten 1:50.000 en de Databank Ondergrond Vlaanderen. In Borremans, M. (ed.). Geologie van Vlaanderen. Academia Press, Gent, 176-183.

Vandenberghe, N., Wouters, L., Schiltz, M., Beerten, K., Berwouts, I., Vos, K., Houthuys, R., Deckers, J., Louwye, S., Laga, P., Verhaegen, J., Adriaens, R. \& Dusar, M., 2020. The Kasterlee Formation and its relation with the Diest and Mol Formations in the Belgian Campine. Geologica Belgica, 23/3-4, this volume. https:// doi.org $/ 10.20341 / \mathrm{gb} .2020 .014$

Vanhoorne, R., Hammenecker, J. \& Gullentops, F., 1999. Sedimentology and palynology of the Upper-Pliocene in the Roer Valley Graben near Maaseik, Belgium. Aardkundige Mededelingen, 9, 169-182.

Van Simaeys, S., De Man, E., Vandenberghe, N., Brinkhuis, H. \& Steurbaut, E., 2004. Stratigraphic and palaeoenvironmental analysis of the Rupelian-Chattian transition in the type region: evidence from dinoflagellate cysts, foraminifera and calcareous nannofossils. Palaeogeography, Palaeoclimatology, Palaeoecology, 208, 31-58. https://doi.org/10.1016/j.palaeo.2004.02.029

Van Simaeys, S., Munsterman, D. \& Brinkhuis, H., 2005. Oligocene dinoflagellate cyst biostratigraphy of the southern North Sea Basin. Review of Palaeobotany and Palynology, 134, 105-128. https:// doi.org/10.1016/j.revpalbo.2004.12.003

Verhaegen, J., Frederickx, L. \& Schiltz, M., 2020. New insights into the lithostratigraphy and paleogeography of the Messinian Kasterlee Formation from the analysis of a temporary outcrop. Geologica Belgica, 23/3-4, this volume. https://doi.org/10.20341/gb.2020.015

Vernes, R.W., Deckers, J., Bakker, M.A.J., Bogemans, F., De Ceukelaire, M., Doornenbal, J.C., den Dulk, M., Dusar, M., Van Haren, T.F.M., Heyvaert, V.M.A., Kiden, P., Kruisselbrink, A.F., Lanckacker, T., Menkovic, A., Meyvis, B., Munsterman, D.K., Reindersma, R., ten Veen, J.H., van de Ven, T.J.M., Walstra, J. \& Witmans, N., 2018. Geologisch en hydrogeologisch 3D model van het Cenozoïcum van de Belgisch-Nederlandse grensstreek van Midden-Brabant / De Kempen (H3O - De Kempen). Studie uitgevoerd door VITO, TNO-Geologische Dienst Nederland en de Belgische Geologische Dienst in opdracht van Vlaams Planbureau voor Omgeving, Vlaamse Milieumaatschappij, TNO, Geologische Dienst Nederland, Nederlandse Provincie Noord-Brabant, Brabant Water, Programmabureau KRW/DHZ Maasregio. VITO rapport 2017/RMA/R/1348, $285 \quad$ p. archief.onderzoek.omgeving.vlaanderen.be/Onderzoek-2314288, accessed 02/12/2020.

Vinken, R. (ed.), 1988. The Northwest European Tertiary Basin. Geologisches Jahrbuch, Reihe A, 100, 508 p.

Vos, K., Vandenberghe, N. \& Elsen, J., 2014. Surface textural analysis of quartz grains by scanning electron microscopy (SEM): From sample preparation to environmental interpretation. Earth-Science Reviews, 128, 93-104. https://doi.org/10.1016/j.earscirev.2013.10.013

Wesselingh, F., Busschers, F.S. \& Goolaerts, S., 2020. Observations on the Pliocene sediments exposed at Antwerpen International Airport (northern Belgium) constrain the stratigraphic position of the Broechem fauna. Geologica Belgica, 23/3-4, this volume. https:// doi.org/10.20341/gb.2020.026

Westerhoff, W., 2009. Stratigraphy and sedimentary evolution. The lower Rhine-Meuse system during the Late Pliocene and Early
Pleistocene (southern North Sea basin). TNO Built Environment and Geosciences - Geological Survey of the Netherlands, Rotterdam, $168 \mathrm{p}$.

Willems, W., 1976. The genus Bolboforma Von Daniels \& Spiegler in the Upper Miocene of northern Belgium. Bulletin de la Société Belge de Géologie, de Paléontologie et d'Hydrologie, 85/1, 3138.

Wong, T., de Lugt, I., Kuhlmann, G. \& Overeem, I., 2007. Tertiary. In Wong, T., Batjes, D. \& de Jager, J. (eds), Geology of the Netherlands. Royal Netherlands Academy of Arts and Sciences, Amsterdam, 151-171. 